\section{Информация для цитирования:}

Худолей Д. М. Парадоксы Кондорсе и их решение // Вестник Пермского университета. Юридические науки. 2017. Вып. 37. С. 288-302. DOI: 10.17072/1995-4190-2017-37-288-302

Khudoley D. M. Paradoksy Kondorse i ikh reshenie [The Condorcet Paradoxes and Their Solution] Vestnik Permskogo Universiteta. Juridicheskie Nauki - Perm University Herald. Juridical Sciences. 2017. Issue 37.

УДК 342.8

DI: 10.17072/1995-4190-2017-37-288-302

\section{ПАРАДОКСЫ КОНДОРСЕ И ИХ РЕШЕНИЕ}

\section{Д. М. Худолей}

Кандидат юридических наук, доцент кафедры конституционного и финансового права

Пермский государственный национальный исследовательский университег

614990, Россия, Г. Пермь, ул. Букирева, 15

ORCID: 0000-001-5870-1537

Статьи автора в БД «Scopus» / «Web of sciences:
В

COI: $10.17072 / 1995-4190-2016-33-258-267$

e-mail: dmitry-hudoley@yandex.ru

Введение: анализируются парадоксы Кондорсе и способы их решения. Цель: опредеить наиболее справедливую избирательную систему на выборах в одно- и многомандатных округах. Методы: использованы общенаучные диалектика, анализ и синтез, абстрагирование и конкретизачия) и частнонаучные методы исследования (формальнооридический, сравнительно-правовой, технико-юридический). Результаты: больиин-

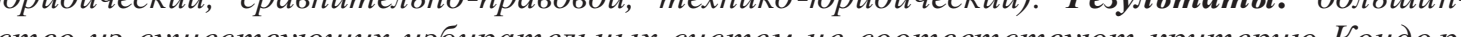
ство из существующих избирательных систем не соответствуют критерию Кондор се. Мажоритарные системы относительного и абсолютного больиинства, основа нные на категориальном голосовании, в ряде случаев приводя $m$ к необоснованным результатам. Больиинство преференциальных систем также не удовлетворяют этому критерию. Существует несколько методик, которые могут позитивно решить первый парадокс Кондорсе. Среди них стоит выделить алгоритмы Шульце, Тайдемана Коупленда, Кемени-Янга. По мнению ряда ученых, алгоритм Маркуса Шульие имеет явные преимущества по сравнению с иными. Данный метод применяется во многи. странах на внутрипартийных выборах, а также при проведении электронного голосования в сети Интернет (в частности, по этому алгоритму избираются кураторы Википедии и некоторых других проектов). Однако и эта методика иеликом парадоксов Кондорсе не решает, в свою очередь порождая ряд других. К сожалению, в настояший момент в России преференциальные системы не могут пр именяться из-за особенностей менталитета избирателей, порядка подсчета голосов, подведения итогов голосования и определения результатов выборов. Выводы: в обществах с истинно двухпсевдодвухпартийной системами парадоксы Кондорсе не возникают. В таких го сударствах использования на президентских выборах двуттуровой маэсоритарной систеин абсолютного больиинства вполне достаточно. Наоборот, в действительно иного-

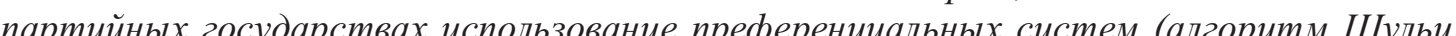
и др.) имеет свои преимущества.

Клочевые слова: избирательное право; избирательная система; (1) ражоритарные системы; преференых систем; проблема общественного выбора;

Information for citation:

Khudoley D. M. Paradoksy Kondorse i ikh reshenie [The Condorcet Paradoxes and Their Solution] Vestnik Permskogo Universiteta. Juridicheskie Nauki - Perm University Herald. Juridical Sciences. 2017. Issue 37. Pp. 288-302. (In Russ.). DOI: 10.17072/1995-4190-2017-37-288-302.

UDC 342.8

DOI: $10.17072 / 1995-4190-2017-37-288-302$

\title{
THE CONDORCET PARADOXES AND THEIR SOLUTION
}

\section{M. Khudoley}

Perm State University

15, Bukireva st., Perm, 614990, Russia

ORCID: 0000-0001-5870-1537

ResearcherID: E-3184-2016

Articles in "Scopus" "Web of Science":

DOI: $10.17072 / 1995-4190-2016-33-258-267$

e-mail: dmitry-hudoley@yandex.ru

Introduction: the article analyzes the Condorcet paradoxes and considers the ways of thei possible solution. Purpose: to identify the fairest electoral system for elections in single- and multi-member electoral districts. Methods: general scientific (dialectic, analysis, synthesis, abstracting, specification) along with specific scientific (formal-legal, comparative law, technicallegal) research methods were used. Results: most of current electoral systems do not meet the Condorcet criterion. The absolute majority and plurality electoral systems based on categorical Coting can in some cases lead to unreasonoble voting results. Most preferential systems lo not

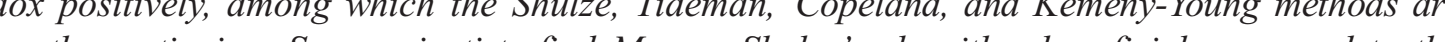
worth mentioning. Some scientists find Marcus Shulzes algorithm beneficial compared to the others. Many countries use this method for intraparty voting and also e-voting on the Internet (e. g., curators of the Wikipedia and some other projects are elected in this way). This approach however, is unable to resolve the Condorcet paradoxes entirely; moreover, it gives rise to some other ones. Unfortunately, nowadays in Russia preferential systems cannot be applied due to some peculiarities of the electorate's mentality, procedures for vote count ing and determination of the election results. Conclusions: the Condorcet paradoxes do not appear in the countries with true two-party or pseudo-two-party systems. At presidential elections such states successfully practice the two-round majoritarian system with the absolute majority. On the contrarys in true multi-party states the use of preferential systems (the Shulze method, etc.) is rather advantageous.

Keywords: electoral law; electoral system; classification of electoral system

problem of public choice; majoritarian systems; preferential systems; semi-proportional system

\section{Information in Russian}

\section{ПАРАДОКСЫ КОНДОРСЕ И ИХ РЕШЕНИЕ}

\section{Д. М. Худолей}

Кандидат юридических наук, доцент кафедры конституционного и финансового права Пермский государственный национальный исследовательский университет 614990, Россия, г. Пермь, ул. Букирева, 15 


\section{THE CONDORCET PARADOXES AND THEIR SOLUTION}

\section{M. Khudoley}

Perm State University

5, Bukireva st. Perm 614990, Russia

ORCID: 0000-0001-5870-1537

Articles in "Scopus"/ "Web of Science":

DOI: 10.17072/1995-4190-2016-33-258-267

e-mail: dmitry-hudoley@yandex.ru

Introduction: the article analyzes the Condorcet paradoxes and considers the ways of their possible solution. Purpose: to identify the fairest electoral system for elections in single- and multi-member electoral districts. Methods: general scientific (dialectic, analysis, synthesis, abstracting, specification) along with specific scientific (formal-legal, comparative law, technicallegal) research methods were used. Results: most of current electoral systems do not meet the Condorcet criterion. The absolute majority and plurality electoral systems based on categorical voting can in some cases lead to unreasonable voting results. Most preferential systems do not meet this criterion either. There are several techniques able to resolve the first Condorcet paradox positively. among which the Shalze. Tideman, Copelond and Kemeny-Young methots a worth menting. Some scientists find Marcus Shulze's algorith beneficial comenods are whers. Many counties use this method for intraparty voting and also e-voling on the Internet (e. (e. g., Curators of the Whipedia and some other projects are elected in this way). This approach however, is unable to resolve the Condorcet paradoxes entirely, moreover, it gives inse to some other ones. Unfortunately, nowadays in Russia preferential systems cannot be applied due to some peculiarities of the electorates mentality, procedures for vote counting and determination of the election results. Conclusions: the Condorcet paradoxes do not appear in the countries with true two-party or pseudo-two-party systems. At presidential elections such states successfully practice the two-round majoritarian system with the absolute majority. On the contrary, in true multi-party states the use of preferential systems (the Shulze method, etc.) is rather advantageous.

Keywords: electoral law; electoral system; classification of electoral systems;

problem of public choice; majoritarian systems; preferential systems; semi-proportional systems

\section{Введение}

В конце XVIII века маркиз Кондорсе перобым обнаружил ряд парадоксальных особенностей, связанных с подведением результатов г олосования. Эти парадоксы, как и апории Зенона, кажутся неразрешимыми. Самый известный парадокс Кондорсе сводится к следуюшей абсурдной ситуации.

Итак, на выборах кандидат А получил 23 голоса, В - 19, С - 18. Предположим, что 23 госа В - 19, С- 18. Предположим, что

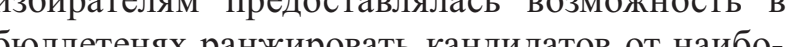
беллетенях ранжироват кандидатов от наибомаркиз Конд до наимене Маркиз Кондорсе угочнил. 23 избирапеля действительно сиитало кандидата А наиболее желаемым, причем на втором месте эти избиратели поставили кандидата В, а на третьем - кандидата С. 17 избирателей поставили кандидата В на первое место, С - на второе, а А - на трегье. 2 гражданина также предпочли кандидата B, но на втором месте в их бюллетенях значится кандидат А, на третьем - кандидат С. 11 че- ловек поставили С на первое, А - на второе, В - на третье. Наконец, 7 избирателей также желают избрания C, но на втором месте в их бюллетенях значится B, а на третьем - A (назовем этот пример первым). Маркиз Кондорсе, опираясь на элементарную математическую логику, потребовал определить кандидата, который будет иметь превосходство во всех парах сравнения с другими кандидатами. Впосах сравн ия с дулм

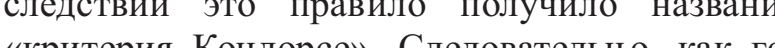
copst

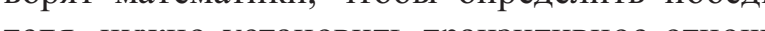

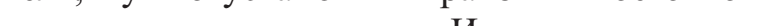
дующую матрицу (табл. 1):

Таблица 1

Матрица парных сравнений

\begin{tabular}{|l|c|c|c|}
\hline \multicolumn{1}{|c|}{ Пары сравнений } & А & В & С \\
\hline А лучше, чем... & & $\mathbf{3 4}$ & 25 \\
\hline В лучше, чем... & 26 & & $\mathbf{4 2}$ \\
\hline С лучше, чем... & $\mathbf{3 5}$ & 18 & \\
\hline
\end{tabular}

ORCID: 0000-0001-5870-1537

ResearcherID: E-3184-2016

DOI: $10.17072 / 1995-4190-2016-33-258-267$

e-mail: dmitry-hudoley@yandex.ru

Введение: анализируются парадоксы Кондорсе и способы их решения. Цель: опреде-

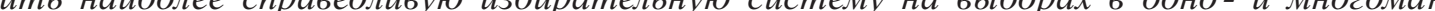
датных округах. Методы: использованы общенаучные (диалектика, анализ и синтез, абстрагирование и конкретизация) и частнонаучные методы исследования (формальноюридический, сравнительно-правовой, технико-юридический). Результаты: большинство из существующих избирательных систем не соответствуют критерию Кондо рсе. Мажсоритарные системы относительного и абсолютного больиинства, основанные на категориальном голосовании, в ряде случаев приводят к необоснованным ре зультатан. Больиинство пресеренииальных систем такәсе не удовлетворяют этоиу критерию. Существует несколько методик, которые могут позитивно решит ь первыи

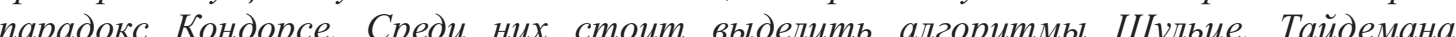

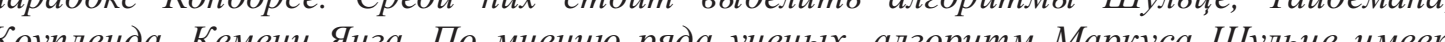

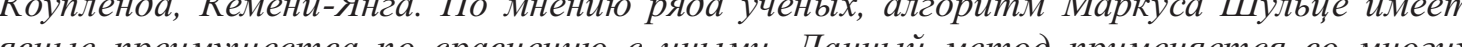
странат иа виутрипартий

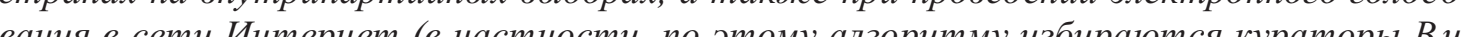

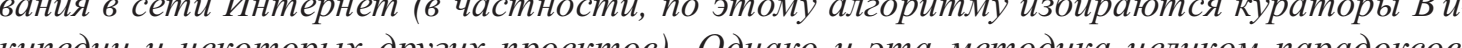

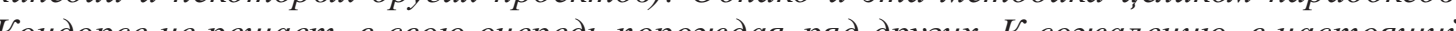

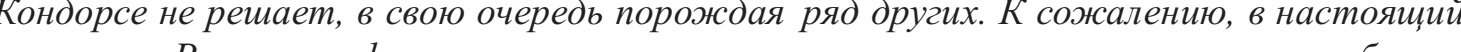
момент в России преференииальные системы не могут применяться из-за особенностей менталтета избрателей, порядка подсчета голосов, подведения итогов гол осования и определения результатов выборов. Выводы: в обществах с истинно двухпсевдодвухпартийной системами парадоксы Кондорсе не возникают. В таких госуда $p$ ствах использования на президентских выборах двухтуровой мажсритарной системы абсолютного больиинства вполне достаточно. Наоборот, в деиствительно много партийных государствах использование преференциальных систем (алгоритм Шульие и др.) имеет свои преимущества.

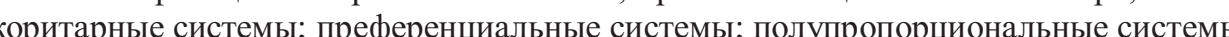

\section{Introduction}

At the end of the $19^{\text {th }}$ century, Marquis of Condorcet was the first to discover a number of paradoxical peculiarities connected with the vote counting. These paradoxes as well as Zeno's paradoxes seem insoluble. The most famous Condorcet paradox comes down to the following absurd situation.

Voting results are as follows: candidate A won 23 votes, candidates $B$ and $C$ won 19 and 18 votes respectively. Suppose that voters in their ballot papers were able to rank the candidates from the most preferable to the least preferable one. Marquis of Condorcet specified the fact that 23 voters actually considered candidate $\mathrm{A}$ the most desirable and these people ranked candidate $\mathrm{B}$ the second and $\mathrm{C}$ the third. 17 voters preferred candidate B, candidate $\mathrm{C}$ was the second and $\mathrm{A}$ was the third in this case. 2 citizens also voted for candidate $B$ but ranked third in their ballots. 11 people chose $\mathrm{C}$ as the most preferable candidate with A taking the second and B the third places. Finally, 7 voters want candidate $\mathrm{C}$ to win but candidate $\mathrm{B}$ is the second in their ballots and $\mathrm{A}$ is the third. Thus, from the perspective of elementary mathematical logic, Marquis of Condorcet required to get the candidate who would have the upper hand in all the pairs when bein compared with other candidates. Later this rule was named the Condorcet criterion. Thus, using the language of mathematics, in order to determine the winner of the election, one should establish transtive relation between the candidates. Consequently, the following matrix can be obtained:

Table

The matrix of pairwise comparisons

\begin{tabular}{|l|c|c|c|}
\hline & A & B & C \\
\hline A is better than... & & $\mathbf{3 4}$ & 25 \\
\hline B is better than ... & 26 & & $\mathbf{4 2}$ \\
\hline C is better than... & $\mathbf{3 5}$ & 18 & \\
\hline
\end{tabular}


В приведенном примере $\mathbf{3 4}$ избирателя считают, что $\mathrm{A}>\mathrm{B}$, а 26 избирателей думают иначе: $\mathrm{B}>\mathrm{A} .25$ человек уверены, что $\mathrm{A}>\mathrm{C}, \mathbf{3 5}$ человек имеют иное суждение: C>A. 42 гражданина решили, что $\mathrm{B}>\mathrm{C}$, а 18 избирателей уверены, что $\mathrm{C}>\mathrm{B}$. Нетрудно заметить, что в паре А и В приоритет имеет А $(\mathbf{3 4}>26)$. В паре А и С преимущество имеет $\mathrm{C}(25<35)$. В паре В и $\mathrm{C}$ приоритет имеет В $(\mathbf{4 2}>18)$ (рис. 1).

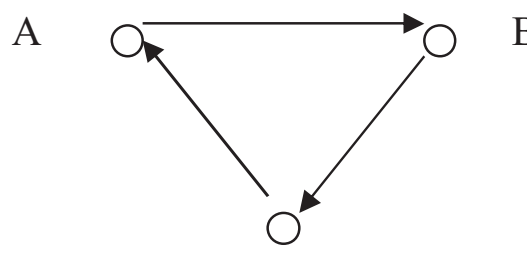

C

Рис. 1. Графическое отображение парадокса Кондорсе

Таким образом, А>B, B $>\mathrm{C}$, но $\mathrm{C}>\mathrm{A}[2$, c. 50]. Круг замкнулся. Отношения между кандидатами нетранзитивные, в силу чего правило Кондорсе применяться не может. Возникает простой вопрос: как решить эту проблему?

Однотуровые избирательные системы,

Отметим, что в большинстве иностранн

Отметим, что в большинстве иностранных языков отсутствует такое понятие, как «относичто слово «большинство» в зарубежных языках этимологически происходит от латинского сл ова «major». Одно из значений данного слова «больше половины». Для обозначения относительного больнинства применяется иной тертель - vonlisy (plurality) Недаро иной термин - «pluralls» (plurality) Недаром большинство западных ученых мажоритарную систему онностель ют мажоритарной, и, следовательно, автомат ически, возникают сомнения в ее демократичности [16, p. 122]. Демократия, основанная на власти большинства (т. е. власти более половины граждан), оказывается в парадоксальной ситуации, когда такого большинства нет.

Авторы предлагали массу решений. Исторически первой избирательной системой в мире была методика одобрительного голосования. В Греции по этому методу проводились выборы до середины XX века. Смысл ее сводится к следующему - избиратель наделяется тем же количеством голосов, что и чиспо участвуюших в выборах кандидатов. Избиратель подает гол за или пролив таслого гендидата. На пралис за или проив калдог кандидага. На практике

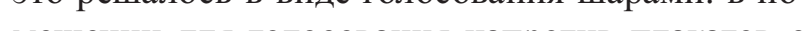

именами кандидатов находились урны с надп исью «за» и «против». Гражданин опускал шарик в ту или иную урну, одобряя или не одобряя ту или иную кандидатуру. Считалось, что голос «за» - белый шар, голос «против» - черный Победителем признавался кандидат, получивший белых шаров больше, чем черных. Слово шар (ball, ballot) впоследствии дало название самому процессу голосования - «баллотировка». Таким образом, избранный кандидат обязан был получить абсолютное большинство голосов избирателей. Нетрудно заметить, что аналогом голосования «против» в примере Кондорсе является третье (т. е. последнее) место, на которо избиратели ставят кандидата в своем бюллетене. Наоборот, первое и второе место може означать белый шар. Так, в первом примере 24 избирател не одобрили кандидата А 24 з бельх шаров), у добрила кандидата (35 бел.х шаров), у кандидақа С - 25 черных шаров. С друюй слороны, лишь 11 избирателей О одобрй кандай В (49 белых шаров). Очевидно, что кандидат В - меньшее из трех зол, это наиболее популярный кандидат и имендолжен победить на выборах!

К сожалению, эта методика одобрительного голосования имеет математические недостатки. Так, предположим, что кандидат А набра 31 голос, на втором месте в его бюллетенях значится кандидат В, на третьем - С. Кандидат В получил 27 голосов, на втором месте в этих бюллетенях значится $\mathrm{C}$, на третьем - А. Наконец, лишь 2 голоса набрал кандидат $\mathrm{C}$, на втором месте в таких бюллетенях находится B, н третьем - А. Назовем этот пример вторым. Если бы в этом случае гр

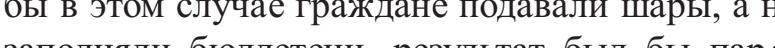
занолнли бюллетен, резульат был бы парадоксальным. Нетрудно заметит, что кандидата А не одобряют 29 избирателей (31 белый шар) У кандидата С результаты хуже - 29 белых шаров и 31 черный. Кандидат В будет объявлен победителем (ни одного голоса против), хотя он получил лишь относительное большинство первых голосов (27). Наоборот, кандидат А, имея абсолютное большинство первых голосов, проиграет выборы!

Существует и ряд других попыток решений парадокса Кондорсе. Так, метод Баклина основан на том, что в случае патовой ситуации первым предпочтениям необходимо присоединить вторые, затем - третьи и т. д. до тех пор, пога гакой-то зандида не нберет абсо тех пор, болей большин иза голосов [18]. В первом примере, котором изложен парадоке маркиза Кондорсе, (19 дител также будет обьявлен кандидат В $(19$ первых голосов +30 вторых голосов $=49)$. Отметим, что методика Баклина, как и система
In the example given, 34 voters think that $\mathrm{A}>\mathrm{B}$, and 26 voters think differently: $\mathrm{B}>\mathrm{A}$; 25 people consider that $\mathrm{A}>\mathrm{C}$, but 35 voters have a different opinion: $\mathrm{C}>\mathrm{A} ; 42$ citizens suppose that $\mathrm{B}>\mathrm{C}$, and 18 voters think that $\mathrm{C}>\mathrm{B}$. It is rather obvious that in the pair $\mathrm{A}$ and $\mathrm{B}$ the priority belongs to $\mathrm{A}(34>26)$, in the pair $\mathrm{A}$ and $\mathrm{C}$ the priority belongs to $\mathrm{C}(25<35)$, and $\mathrm{B}$ is in priority in the pair $\mathrm{B}$ and $\mathrm{C}(42>18)$.

A

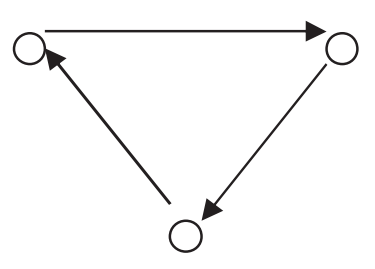

B

C

Fig.1. Graphic representation of the Condorcet paradox

Thus $\mathrm{A}>\mathrm{B}, \mathrm{B}>\mathrm{C}$, but $\mathrm{C}>\mathrm{A}[2$, p. 50]. It looks like an endless cycle. The relationships between the candidates are not transitive, that is why the Condorcet rule cannot be applied. Thus, the question arises how to solve this problem?

\section{Single-Ballot Electoral System}

That Do Not Meet the Condorcet Criterion

It should be noted that a large number of foreign languages lack the conception of "relative majority". It can be explained by the fact that the word "majority" comes from the Latin "major" meaning "more than half". But to speak about relative majority the term "pluralis" (plurality) is used. It is not a coincidence that most Western scientists do not treat plurality voting as a majoritarian system and so are skeptical about its democratic nature [15, p. 122]. The democracy based on the majority rule (i. e. the power of more than half of citizens) gets into a paradoxical situation in case such majority is absent.

A lot of possible solutions have been suggested. Historically the first electoral system in the world was approval voting, which had been used in Greece up to the middle of the $20^{\text {th }}$ century. It works as follows: a voter is given a number of votes identical to the number of candidates and he/she casts a vote for or against each candidate. In practice, it was the voting by black and white balls. In the room where the election was held two ballot boxes were placed in front of each candidate's placard; one of the boxes had an inscription "yes" on it while the other one had "no". A voter put a ball into a box showing his/her approval or disapproval of a particular candidate. The white ball was considered "for" while the black one meant 'against'. The candidate with the maximum number of white balls was the winner of the election in case the number of white balls was larger than that of black ones. Thus, the name of the procedure "ballot" takes its origin from the word "ball". So, the candidate elected was supposed to have the absolute majority of votes. Clearly, the third (or the last) place in the Condorcet's example is analogous to the black ball whereas the first and the second places in the ballot paper are comparable to the white ball. Thus, in the first example 24 candidates did not approved of candidate A ( 35 white balls), candidate $C$ got 25 black balls. On the other hand, only 11 voters disapproved of candidate B ( 49 white balls). Evidently, it is candidate $\mathrm{B}$ who is to win the election!

Unfortunately, this practice of the approval voting has some drawbacks if being looked at in terms of mathematics. Let us assume that candidate A got 31 votes, with candidate $B$ on the second and candidate $\mathrm{C}$ on the third place. In the ballot papers where candidate $\mathrm{B}$ received 27 votes candidate $\mathrm{C}$ was the second and A was the third. Finally, only 2 votes were given to candidate $\mathrm{C}$, and in such ballots candidates B and A took the second and the third place respectively. Let this example be named the second. If in this case citizens had used black and white balls instead of filling in ballot papers, the result of the election would have been paradoxical. Obviously, candidate A is disapproved of by 29 voters ( 31 white balls); a bit worse is the situation with candidate $\mathrm{C}$ that has 29 white balls and 31 black ones; with that candidate B wins the election by plurality (having no "against" votes), although he only received 27 electoral votes. And paradoxically, having the absolute majority candidate A will lose the election!

There have been some other attempts to resolve the Condorcet paradox. One of these is Bucklin method based on the idea that in case of a stalemate, the voters' primary preferences should be added by the second and then by the third ones, and it should be repeated until some candidate gets the absolute majority of votes [18]. In the first above example presenting the Condorcet paradox, candidate $\mathrm{B}$ will win the election (as having 19 first votes +30 second votes $=49$ ). Here it should be mentioned that both Bucklin method and the approval voting 
одобрительного голосования, может привести к тому, что два или более кандидата получат а ббому, нор два или более кандидата получат абсризэн сов) Так, в тервом примере кендида С

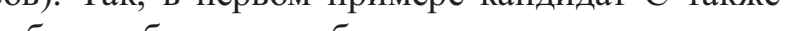
саберет абсолюоное большинств, но проитрает выборы (18 первых голосов + 17 вторых $=35)$. Здесь мы видим не более чем манипуляцию с числами. Мы не согласны с методикой Баклина в том, что он де-факто приравнивает первые предпочтения вторым. Это может привести к несправедливому результату.

Приведем весьма демонстративный третий пример. Пусть 3 избирателя решили, что $\mathrm{A}>\mathrm{B}>\mathrm{C} .1$ гражданин уверен, что $\mathrm{A}>\mathrm{C}>\mathrm{B} .2$ человека решили, что $\mathrm{B}>\mathrm{A}>\mathrm{C}$. Еще один избиратель имеет несколько иное мнение: $\mathrm{B}>\mathrm{C}>\mathrm{A}$ Наконец, 6 человек определили, что $\mathrm{C}>\mathrm{A}>\mathrm{B}$. Никто из кандидатов не набрал абсолюо $>$.

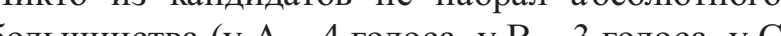

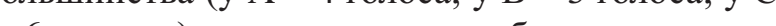
- 6 голосов), поэлому мы прибавляем вторые преференции к первым. В итог, у А - 12 голосов, У В - 6 голосов, у С - 8 голосов. Кандидат А признается победителем. Однако правило Кондорсе требует избрания кандидата С. С $>\mathrm{A}$ $(7>6), \mathrm{C}>\mathrm{B}(7>6)$ и $\mathrm{A}>\mathrm{B}(10>3)$, т. е. $\mathrm{C}>\mathrm{A}>\mathrm{B}$ ! Неудивительно, что в США метод Баклина сразу же после своего первого использования на выборах был признан неконституционным.

Метод Борда исправляет недостаток, который содержится в алгоритме Баклина. Стоит сказать, что, по всей видимости, автором этой системы первоначально был не французский ученый Борда, а известный философ Николай уребс, более изестий как Николай Кузаколай Как, болй кандид

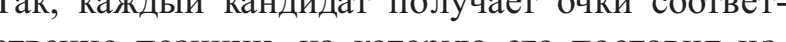

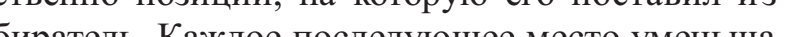
браль. Каждое носледующее место уменьшает рейтинг на единицу. Победитель определяется просым большинсльом онков. В настоящее время имеется различное количество модификаций этого метода. В одних случаях авторы считают, что первая преференция должна быть равна $\mathrm{n}$ очкам, где $\mathrm{n}$ - число участвующих кандидатов (последнее место равно одному очку). Другие авторы считают, что для удобства вычисления за первое место следует давать n-1 баллов (последнее место в этом случае вообще не оценивается) [18]. Отдельные авторы предлагают предоставить право избирателю - определить роред мер, три), следов ер, три), следовалельно, кандидат, получивший басл балл (так называсмый модифицированый меод Борда). В чистом виде метод Борда в мире практически не применяется, однако в Науру на парламентских выборах в многомандатных округах избиратель может определить 3 преференции, первая равна голосу, вторая - половине, третья - одной трети голосов [15, p. 355]

Используем правила метода Борда в первом римере, демонстрирующем парадокс маркиз Кондорсе. Если первое место равно n-1 баллам, то победителем опять-таки будет объявлен ка дидат В $(19 * 2+30 * 1=68)$, на втором месте окажется кандидат А $(23 * 2+13 * 1=59)$, а на третье кандидат C $(18 * 2+17 * 1=53)$. Данный пример еще раз демонстрирует, что именно кандидат В наиболее популярный кандидат. Недостатки системы Борда такие же, как и системы одобрительного голосования - победителем може быть объявлен кандидат меньшинства. Так, нашем втором примере кандидат А получи 62 очка, В - 87, С - 31. Следовательно, системы 62 ола, В - 87, С - 1 . Следовательно, систем . критерия Кондорсе, нару иог друюй основной

Также выяснилось, что методика Борда и ее азновидности не дают адекватных результатов многомандатном округе. Чтобы устранит этот пробел, английским ученым Майклом Даммиттом была разработана так называема система квоты Борда. Однако и эта модификация системы Борда не всегда справедлива имеет те же недостатки, что и классический метод [19, p. 177].

\section{Двух- и многотуровые системы, а также}

алогичые им преференциальнь критерию Кондорсе

Одно из очевидных предложений, чтобы определить победителя в той ситуации, когда никто из кандидатов не получил абсолютного большинства голосов, - проведение второго тур. Но кто должен принять участие во втором

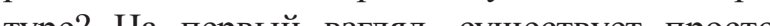

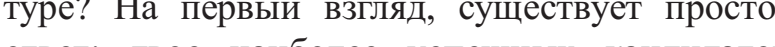
оввег: двое нанболее уснешных кандидатов.

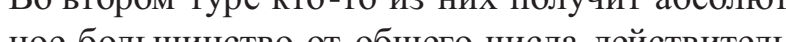
ное большинство от общего числа действительных бюллетеней. Следовательно, в этом случае будет искусственным образом получено абсоютное большинство

Многотуровые системы в настоящий момент не используются на выборах в представительнье органы власти. Однако многие партии используют такие методики на внутрипартийных выборах (праймериз). Смысл этого метода заключаются в том, что необходимо искюючать кандидата с наименьим голичеством голосов перед камдым ется абсолютным большинством. system can lead to the situation when two or more candidates will receive the absolute majority (the candidate having received the most votes will win). Thus, in the first example candidate $\mathrm{C}$ will also get the absolute majority of votes but will lose the election (having 18 first votes +17 second votes $=35$ ). And this is nothing else but manipulation with numbers. We disagree with Bucklin method as it sets the first and the second preferences equal de facto, which can lead to the unfair election result.

Let us consider one more example. Suppose that 3 voters think that $\mathrm{B}>\mathrm{A}>\mathrm{C} ; 1$ citizen thinks that $\mathrm{A}>\mathrm{C}>\mathrm{B}$; and 2 people consider that $\mathrm{B}>\mathrm{A}>\mathrm{C}$; finally 6 voters think that $C>A>B$. Thus, none of the candidates won the absolute majority of votes (A won 4 votes, $\mathrm{B}-3, \mathrm{C}-6$ ) so we have to add the first and second preferences. Having summarized all the above, we can see that A received 12 votes, B won 6 votes and $C$ was given 8 votes. In this situation, candidate $\mathrm{A}$ wins the election. However, according to Condorcet rule it is candidate $\mathrm{C}$ who is to win: $\mathrm{C}>\mathrm{A}(7>6), \mathrm{C}>\mathrm{B}(7>6)$ и $\mathrm{A}>\mathrm{B}(10>3)$, that is $\mathrm{C}>\mathrm{A}>\mathrm{B}$ ! Naturally, in the USA Bucklin method was ruled unconstitutional.

The Borda count corrects the failing of the Bucklin method. It should be mentioned that originally this system is likely to have been suggested by a famous philosopher Nicholas Krebs, better known as Nicholas of Cusa but not by the French scientist Jean-Charles de Borda after whom it was named. According to this system, each candidate gets votes in accordance with the rating given him/her by the voters. However, each lower position received by the candidate reduces his/her rating by one. And the winner is determined simply by the majority of points. Currently, there are several modifications to this method. One of these is that the first preference should be equal to $\mathrm{n}$, where $\mathrm{n}$ is the number of candidate taking part in the election (the last place brings one point). According to another interpretation, to simplify the calculation each first place should bring a candidate $\mathrm{n}-1$ points (in this case the last place is not taken into account) [18]. Also there is a suggestion to provide a voter with the right to determine a limited number of preferences (e. g. 3); therefore, the candidate ranked the third, i. e. receiving the third preference, wins only one point (it is so called modified Borda count). The Borda count has been hardly applied as it is, although in Nauru at parliamentary elections in multi-member electoral districts a voter can determine three preferences, the first one being equal to a vote, the second and the third ones - to a half and a third of a vote respectively [15, p. 355].

Let us apply the Borda count to the first example demonstrating the Condorcet paradox. If the first place equals $n-1$ points, candidate $B$ will win the election $(19 * 2+30 * 1=68)$, the second place will be taken by candidate $\mathrm{A}(23 * 2+13 * 1=59)$, and candidate $\mathrm{C}$ will be on the third position $(18 * 2+13 * 1=53)$. The example given confirms that candidate B is the most popular one. The main drawback of the Borda count is similar to that of the approval voting system and it is the fact that the minority candidate can win the election. Thus, in the second example candidate $\mathrm{A}$ will get 62 points, B -87 and $C-31$. Therefore, both the Borda coun and approval voting system (apart from the Condorcet criterion) do not meet the most important criterion of democracy, which is the majority rule

It has also been found out that the Borda coun and its varieties do not provide adequate results when applied in a multi-member electoral district. To correct this fault, the English scientist Michae Dummett developed so called "Quota Borda System" (QBS). However, this modification to the Borda count proved not to be always fair and to have the same drawback as the classical method does [19, p. 177].

Two-Round and Multi-Ballot Electora Systems and Analogous Preferential Methods not Conforming to the Condorcet Criterio

In the situation when none of the candidates won the absolute majority of votes, one of the most obvious solutions is to hold a second ballot. But who is to contest the election? The answer seem obvious - two most successful candidates. Apparently, one of them will receive the absolute majority from the total number of valid ballot papers. Consequently, the absolute majority will be achieved in this case in such an artificial way.

Nowadays multi-ballot systems are not used at elections to representative bodies but a lot of parties practice these at primaries. This method aims at the elimination of the candidate having the fewest votes before each election round, where the absolute majority determines the winner. 
Другое решение патовой ситуации - различные методики преференциального (рейтингового) голосования. Они основаны на том, что избиратель ранжирует кандидатов от наиболее избиратель ранжирует кандидатов от наиболее предпочитаемых до наименее желаемых. Имен-
но такое голосование проводилось в вышеизлоно такое голосование проводилось в вышеизло-
женном примере Кондорсе. Однако в больши нженном примере Кондорсе. Однако в больши н-
стве преференциальных систем искусственным стве преференциальных систем искусственным образом моделируются многотуровые системы и, следовательно, кандидаты, которые получили меньшинство первых голосов, латов. Так, самая процедуры распределения мардеренциальная система - система альтернативного голосования (или немедленного второго тура). Авторами этой методики являются американский професcop Роберт Уэйр и английский барристер Томас Хэйр $[1$, c. $88 ; 6$, c. $104 ; 8$, c. 167$]$. Она матемаХэйр $[1$, с. 88 ; 6, с. $104 ; 8$, с. 167$]$. Она математическ моделирует влорой тур, определяя победителя эно лосования без ето проведен. Счйаеся, что избиратель определил заместителей кандидатов в своем бюллетене. В силу этого разрешается передать голоса кандидата, который получил меньше всех первых голосов, его заместителю (т. е. кандидату, который значится на втором м есте в данном бюллетене). Если в этом гипотетическом втором туре не будет определен победитель, необходимо устранить еще одного кандидата и провести виртуальный третий тур и т. д.

Существуют и иные методики преференциальных систем, которые моделируют двухтур овые мажоритарн шиле систе на воболах мра Лондона применясся си бема доких ратель в бгллетеня первым голосом определ яет избранного кандидата, а вторым - его заместителя. Если нико из кандиданов не получил абсолютного большинства, то устраняются все кандидаты, кроме первых двух, к их первы олосам присоединяются вторые [9, с. 45$]$

Все вышерассмотренные системы в первом примере маркиза победу отдают кандидату А. Несправедливость налицо. Более того, все эти системы ранее рассмотренному критерию Кондорсе вообще не соответствуют и, в силу этого, несправедливы. Изменим рассматриваемый первый пример, чтобы более убедительно доказать ушербность методики двух- и многотурового голосования и тех преференииальных систем, которые моделируют второй и последу иший туры. Пусть 23 избиртеля в своих боле щий туры. Пусы 23 избирателя в своих бюллетенях на перьом месте поставили кандидата А, на втором - C, на трепьем - В. 20 граждан поставили кандидата В на первое место, С - на
второе, А - на третье. 17 избирателей отдали свои голоса С, но его первым заместителем свои голоса С, но его перия заместелем сте. В паре А и В приоритет принадлежит В (23<37). B A n B u C $(23<37)$. В $(23<37)$. В п्ре B и $\mathrm{C}$ приорите имеет С $(20<\mathbf{4 0})$. Назовем этот пример четвертым. Таким образом, B >A, C>A и C>B. Принцип транзитивности математики, предложенный Кондорсе требует от нас признания кандидата С наиболее желаемым среди всех кандидатов. Но он заня последнее место по числу первых голосов (только 17) и, следовательно, лишился всех шансов на победу, так как не будет допущен ко второму туру голосования. Большинство преференциальных систем также объявляют его проигравшим, поскольку предполагают исключение кандидата, получившего наименьш
первых предпочтений $[2$, с. 94; 7, с. 18$]$.

Не надо думать, что этот пример - плод спекулятивной фантазии математиков. Похожая ситуация имела место во Франции в 2002 г. на президентских выборах. В первом туре никто из основных кандидатов не смог набрать абсолютного большинства: правоцентрист Ж. Шира набрал 19,88 \% голосов, ультраправый кандидат Ж.-М. Ле Пен получил 16,86 \% голосов, социалист Л. Жоспен - 16,18\% голосов. Во втором туре Ширак легко победил Ле Пена, собрав 82 , $21 \%$ голосов избирателей. Однако, по мнению ряда социологов, в парном сравнении социалис Жоспен опережал и Ширака, и Ле Пена. Жоспен, следуя закону математики, должен бы выиграть выборы, но, согласно французскому избирательному закону, их проиграл! Это дало полод усон крал џрай. Отдельные траждане даже назыв

Чтобы исправить данный недостаток, в некоторых странах разрешают участвовать во вт ором туре не двум, а большему числу кандидатов. Так, в той же Франции на парламентских выборах во второй тур проходят кандидаты, п олучившие не менее 12,5 процентов голосов избирателей. Следовательно, во втором туре могут участвовать максимум 8 кандидатов. Но в четвертом примере подобное правило все равно не позволяет кандидату С победить. Очевидно, что во втором туре для избрания кандидат должен получить лишь относительное большинство, а не абсолютное. По сути, в данном случае выборы с

Более того, даже если допустить, что в четвертом примере будут избираться два депутата, а не один, то это все равно не позволит кандида-
Different preferential voting systems can also be used to tackle the stalemate. These are based on the principle when a voter ranks candidates from the most to the least preferred. And this is the type of voting which was shown in the above Condorcet example. However, most preferential voting multiballot systems are modeled artificially and so the candidates receiving the minority of the first voices are eliminated from the seat allocation procedure. The most common preferential system in the world is the alternative vote system (or instant second round). The authors of this method are the American professor Robert Ware and English political scientist Thomas Hare $[1$, p. 22; 6, p. 104; 8, p. 167]. It creates a mathematical simulation of the second round and determines the winner of this hypothetical second voting without it being held. In other words, a voter in his/her ballot paper is meant to have identified the alternate candidates. Therefore, it is allowed to pass the votes received by the candidate with the fewest first ones to his alternate (i.e. the candidate ranked the second in this ballot paper). And if this hypothetical second round does not make it possible to determine the winner, then one more candidate should be eliminated through a third hypothetical tour and etc.

There are some other types of preferential systems that simulate two-round absolute majority voting systems. For example, in London at mayoral elections the second vote system is applied. A voter uses his/her first vote to determine the candidate to be elected and the second one for his/her alternate. If none of the candidates wins the absolute majority, all the candidates except the first two are eliminated, their first votes being added to the second ones $[9$, p. 45]

According to all the systems considered above, candidate A wins the election in the first example of Condorcet. Unfairness is obvious here. Moreover, all these systems do not meet the earlier considered Condorcet criterion at all and therefore are unfair. Let us alter the first example in order to prove the invalidity of the method of two-round and multi-ballot voting and preferential systems simulating the second and the following rounds. Suppose that 23 voters chose candidate $A$ as their main preference and candidates $\mathrm{C}$ and $\mathrm{B}$ were the second and third respectively. 20 citizens preferred candidate $\mathrm{B}$ and gave the second place to $\mathrm{C}$ and the third one to $\mathrm{A}$. Candidate $\mathrm{C}$ was the leader in 17 ballot papers, with $\mathrm{B}$ taking the second position and $\mathrm{A}$ the third. In the pair A and B the priority is given to B $(23<37)$; in the pair A and C the priority is given to $\mathrm{C}(23<37)$; and between $\mathrm{B}$ and $\mathrm{C}$ the most pre erable candidate is $C(20<40)$. Let it be the fourth example. Thus, $\mathrm{B}>\mathrm{A}, \mathrm{C}>\mathrm{A}$, and $\mathrm{C}>\mathrm{B}$. According to the transitive principle in mathematics suggested by Condorcet, candidate $\mathrm{C}$ should be pronounced the winner of the election. But this candidate received the lowest number of first votes (only 17) an therefore lost all chances to win as he would be unable to take part in the second round of the election. He will also be pronounced the looser by the majority of preferential systems since according to these the candidate with the lowest number of first votes is to be eliminated [2, p. 94; 7, p. 18].

The above example should not be thought of as a result of mathematicians' speculative imagination. Similar situation happened at the presidential election in Paris in 2002. In the first round none of the candidates could win absolute majority of votes: center-right Jacques Chirac got 19,88 \%, far right candidate Jean-Marie Le Pen received $16,86 \%$, and socialist Lionel Jospin was given $16,18 \%$ of votes. The second round was held, in which Chirac, having received $82,21 \%$, easily won Le Pen. However, some sociologists mention that if to draw paired comparisons, Jospin was ahead of both Chirac and Le Pen, and thus following the law of mathematics was bound to win the election, but lost it due to French election law! This fact put into question the fundamentals of French democracy. Chirac was even named 'illegitimate president' by some citizens [5]

In order to overcome this drawback, some countries allow more than two candidates to contest election. For example, at parliamentary election in France candidates receiving not less than $12,5 \%$ of votes go forward to the second round. Therefore, the maximum number of candidates in the secon round is 8 . Nevertheless, in the fourth given example the above presented rule will not allow candidate $\mathrm{C}$ to win the election. It is obvious that in order to win a candidate should get plurality, not the absolute majority of votes. In fact, in this case the second round appears to be just a repeat election with approximately the same results.

Moreover, even if to assume that in the fourth example not one but two candidates will be elected it will not let candidate $\mathrm{C}$ to win. In the $19^{\text {th }}$ century, 
Т. Хэйр, английский юрист Г. Друп, датский математик К. Андрэ и английский математик математик К. Андрэ и английский математик 1. Хилл в XIX веке разработали систему единоо передаваемого голоса, которая является м одирикац й системы альтернативного голос ования для применения на выборах в многомандатном округе. Существует значительное число модификаций системы единого передаваемого голоса (Хэйра-Кларка, включающего метода Грегори, взвешенного включающего метода Грегори, метод Мика и др.), но все они основаны на том, что необходимо исключать кандид ата с наименьшим числом первых предпочтений. Таким образом, все модификации системы единого передаваемого голоса будут приводить к такому несправедливому результату [4, с. 164].

Как мы убедительно показали выше, неббосновано искюч рандидат с наименьиим количеством первых 作 Кумбса основан на том, чтобы в первую очередь исключать кандидата с наибольшим количеством последних голосов. Затем будет происх одить пересчет первых голосов. Такое исключение и пересчет голосов будет совершаться до тех пор, пока кто-нибудь не наберет абсолютн ого большинства голосов [18]. На первый взгляд, эта методика имеет преимущества перед иными, но и она не лишена недостатков. Как выяснилось, этот метод противоречит правилу Кондорсе. Несколько изменим третий пример. Пусть 3 избирателя решили, что $\mathrm{A}>\mathrm{B}>\mathrm{C}, 1$ гражданин уверен, что $\mathrm{A}>\mathrm{C}>\mathrm{B}, 2$ челове $B>A>C$. Еще один избиралель имес нел, $\mathrm{B}>\mathrm{A}>\mathrm{C}$. Еще один избраль ине $\mathrm{C}>\mathrm{A}>\mathrm{B}$, a 3 г. 3 челевек определили, что $\mathrm{C}>\mathrm{A}>\mathrm{B}$, а 3 гражданина уверены, что C $>$ B $>$ A. Поскольку никто из кандидатов не набрал абсолютного большинства, кандидат С исключается и победителем признается кандидат А с 7 голосами из 13. Однако правило Кондорсе требует от нас признания кандидата $\mathrm{C}$ избранным: $\mathrm{C}>\mathrm{A}(7>6), \mathrm{C}>\mathrm{B}(7>6)$ и $\mathrm{A}>\mathrm{B}(7>6)$, т. е. $\mathrm{C}>\mathrm{A}>\mathrm{B}$ !

\section{Преференциальные системы, способные}

\section{решить первый парадокс Кондорс}

В настоящий момент учеными разработано множество систем, которые могут решить парадокс Кондорсе и, одновременно, соответствовать одноименному критерию. Практически все такие алгоритмы могут применяться лишь случая слу скольку должно осущест

Далее мы будем рассматривать эти сист емы в зависимости возрастания их математиче- ских достоинств. Английский математик Ч. Доджсон (более известный как Л. Кэрролл,

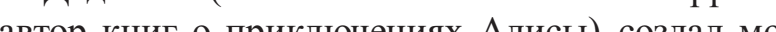

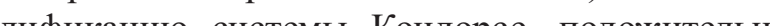

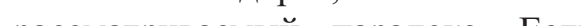
реден обнаруживается цикл, мандат передается кандидату, в отношении которого потребуется пр оизвести наименьшее количество исправлении в бюлле телем по правилам транзитивности [12, p. 158] В первом примере маркиза кандидат А лучше В (34>26), кандидат В лучше С (42>18), кандида С лучше А $(35>25)$. Чтобы кандидат А стал победителем, необходимо изменить знак последней пары на $\mathrm{A}>\mathrm{C}$. Для этого, в свою очередь, потребуется изменить 6 бюллетеней избирателей (новое соотношение будет в пользу А $31>29$ ). Чтобы кандидат В стал победителем необхо . Для этоло поребу Для этор поребуелья измениь 5 боллетене

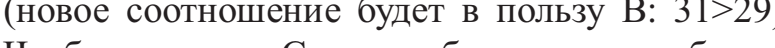
Чтобы кандидат С стал победителем, необход имо изменить вторую пару суждения. Для этого потребуется изменить 13 бюллетеней (ново соотношение будет в пользу С - это 31>29).

Отдельные авторы пытались иначе решит парадокс Кондорсе - путем гибридизации метода Борда и преференциальных систем, моделирующих второй тур. Три из таких модификаций заслуживают внимания - алгоритмы Нансона, Болдуина и Роуза. По методу Болдуина, наоборот, аннулируются все предпочтения, отданные за кандидата, получившего наименьшее колич ство очков по системе Борда, затем происходит

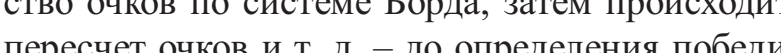
иим кандидатом по кол ио оков Борда является кандидат С (53 очпобеждает А (34>26). Мы тоже не согласны м Секим результатом.

Согласно методу Нансона, необходимо а ннулировать все предпочтения, отданные кандидатам, которые получили баллы, меньшие или равны арифметически среднему количеству очков по методу Борда. Если мандаты остались нераспределенными, необходимо снова вычи слить арифметически среднее количество очков и аннулировать предпочтения. Такое и сключение следует производить до тех пор, пока не останется один избранный кандидат $[14$, p. 373]. В первом примере маркиза Кондорсе сре 373$]$ В

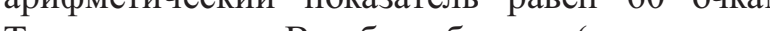
тего 68 бал), он

Meri $\mathrm{Poy})$,

Метод Роуза более сложен. Сначала нео б- mentioned above T. Hare, another English lawyer H. Droop, Danish mathematician C. Ande, and English mathematician T. Hill developed the system of single transferable vote (STV), which is a modification to the alternative vote system designed to be applied in multi-member electoral districts. There are quite a number of modifications to the alternative vote system (these are by Hare-Clark including Gregory method, weighted inclusive Gregory method, Mick method); but they all are based on the necessity to eliminate the candidate having the lowest number of first preferences. Therefore, any modifications to the single transferable vote system will lead to this unfair result [4, p. 164].

As it was convincingly shown above, even if the situation is disputable there are no good reasons to eliminate the candidate having the lowest number of first preferences. A different criterion must be used. There is Coombs' method which is based on the elimination of those candidates first who received the largest number of last preferences. Such elimination and recounting of votes will be performed until some candidate wins the absolute majority of votes [18]. However, this method, although having obvious advantages over the other ones, is not free of drawbacks. It has been found out that Coombs' method goes into a contradiction with the Condorcet rule. Let us change the third example in some way. Assume that 3 voters decided that $\mathrm{A}>\mathrm{B}>\mathrm{C}$; 1 person thinks that $\mathrm{A}>\mathrm{C}>\mathrm{B}$; and the opinion of 2 citizens is that $B>A>C$; there is 1 person who ranked the candidates as $\mathrm{B}>\mathrm{C}>\mathrm{A}$, and 3 voters decided that $\mathrm{C}>\mathrm{B}>\mathrm{A}$. As far as none of the candidates won the absolute majority, candidate $\mathrm{C}$ is eliminated and candidate $\mathrm{A}$ wins having 7 votes out of 13 . However, the Condorcet rule requires $\mathrm{C}$ to be pronounced the winner since $\mathrm{C}>\mathrm{A}(7>6), \mathrm{C}>\mathrm{B}$ $(7>6)$ and $\mathrm{A}>\mathrm{B}(7>6)$, i.e. $\mathrm{C}>\mathrm{A}>\mathrm{B}$ !

\section{Preferential Systems Capable}

\section{of Solving the First Condorcet Paradox}

Currently scientists have developed plenty of systems able to solve the Condorcet paradox and simultaneously meet the Condorcet criterion. Almost all such algorithms can be used provided the votes are counted electronically as the process takes a huge number of operations.

Further these systems will be considered according to the increase in their mathematical benefits. The English mathematician Ch. Dodgson (better known as L. Carroll, the author of the books about Alice's adventures) developed a Condorcet system modification that positively solves the paradox under consideration. If it comes out to be a cycle the mandate is passed to the candidate whose ballot papers need the fewest corrections for him/her to be pronounced the winner in accordance with the rules of transition [12, p.158]. In the firs Condorcet example, candidate $\mathrm{A}$ is better than $\mathrm{B}$ (34>26), candidate B is better than C $(42>18)$, and candidate $\mathrm{C}$ is better than $\mathrm{A}(35>25)$. For candidate A to win, it is necessary to change the mathematical symbol in the latter pair like $\mathrm{A}>\mathrm{C}$. But to do this it is necessary to alter 6 votes (the new ratio will be in favor of A: 31>29). For candidate B to win, it is necessary to change the mathematical symbol in the former pair like $\mathrm{B}>\mathrm{A}$. But to do this it is necessary to alter 5 votes (the new ratio will be in favor of $\mathrm{B}$ : $31>29$ ). For candidate $C$ to win, the second pair of the sentence has to be altered and so 13 ballot papers will have to be corrected (the new ratio will be in favor of C: $31>29$ ).

Some authors have tried to solve the Condorcet paradox in a different way, through the hybridization of the Borda count and preferential system simulating the second round. Three of these modifications are worth noticing. They are algorithms by Nanson, Baldwin and Rose. According to Baldwin's method, all the preferences given to the candidate having received the fewest votes according to the Borda system are annihilated and the recount of voices continues until the winner is determined $[3$, p. 60]. The Borda count states that the worst candidate is C (53 votes). After he/she has been eliminated and the votes have been recounted, candidate $\mathrm{A}$ is to win $(34>26)$. However, we do no agree with this result either.

According to Nanson's method those preferences should be annihilated which were given to candidates receiving a smaller or arithmetically equal to the average number of votes in terms of the Borda count. And if it is still impossible to give out mandates, then the average number of points has to be found arithmetically and preferences are to be annihilated. Such elimination should be held as long as one candidate is left [14, p. 373]. In the firs Condorcet example, the arithmetic average is equal to 60 points. Of all the candidates only candidate $\mathrm{B}$ has more than that (68), and so he is pronounce the winner.

Rose's method is more complicated. At first, the candidate having the most), points according to 
наибольшим количеством очков по методу Бо рда и аннулировать его преференции. Если да и аннулировать его преференции. Если

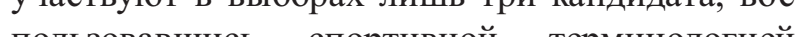
пользовавшись спортивнй терминологией, можно залвиь, чюо такой временно отстраненный кандидат напрямую проходит в финал. 3aтем мы производим пересчет очков по методу Борда среди оставшихся кандидатов, снова временно отстраняем кандидата с наибольшим количеством очков, направляя его в финальный раунд голосования. Далее мы проводим финал, восстанавливая временно отстраненных кандидатов, и заново пересчитываем очки по методу Борда [13]. Нетрудно заметить, что при большом количестве кандидатов возникает гиган тское количество промежуточных раундов (полуфиналов, четвертьфиналов и проч), количелуро произволимых операций возрас), количеметрической прогрессии!

Так, в первом примере маркиза мы должны временно отстранить кандидата В, который сразу проходит в финал. Кандидат $\mathrm{C}$ побеждает кандидата А $(35>25)$, но в финале проигрывает B (42>18).

Для решения парадокса Кондорсе методика альтернативного голосования была несколько изменена Робом Ле Грандом (для выборов в одномандатном округе) и Яном Коком (для выб оров в многомандатных округах) [13; 18]. Смысл в том, что устраняемый кандидат определяется не по числу первых голосов, а в гипотетическом «утешительном» туре среди кандидатов наименьшим количеством первых голосов (такую метолику авторы назвали системой кмгновенното второго тура среди нихудй мен овенно B

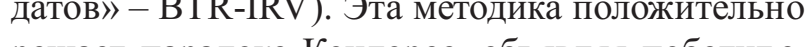
решает парадокс Кондорсе, обьявляя победит елем кандидата A. Так, напxудим кандидат ами по числу первых голосов являются В (19 голосов) и С (18 голосов). Как мы уже говорили, в этой паре приоритет принадлежит В (42>18), следовательно, именно кандидат С признается наихудшим, его голоса передаются А (11 дополнительных голосов) и В (7 дополнительных голосов). Кандидат А признается победителем.

Мы не будем анализировать все недостатки этих методик. Однако стоит отмети ть главный: имеет место нарушение правила монотонности (математик Дуглас Вудалл называл это правило mono-raise) [18]. Иначе говоря, использоване алгоритма м0ж . Иу изменение префере измег ( сторону (например, со вторых на первые) при-

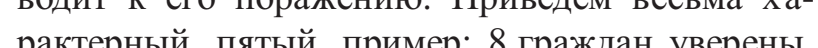
рактерный, пятый, пример: 8 граждан уверены,
что А $>\mathrm{B}>\mathrm{C}$. 4 человека решили, что $\mathrm{C}>\mathrm{A}>\mathrm{B}$. 5 избирателей определили, что $\mathrm{B}>\mathrm{C}>\mathrm{A}$. Наконец, 3 гражданина уверены, что С $>\mathrm{B}>\mathrm{A}$. Так, согласу М ду Болдуина, у кандидата А - 20 баллов, у В - 21 балл, у С - 19 баллов. Мы устраняе кандидата С как обладателя наименьшего кол ичес приоритет имеет А $(12>8)$. Кандидат А получае

Теперь мы несколько изменим пример. Допустим, что последние три избирателя, которые голосовали $\mathrm{C}>\mathrm{B}>\mathrm{A}$, несколько поменяли свои убеждения и проголосовали $\mathrm{C}>\mathrm{A}>\mathrm{B}$. На первый взгляд, кандидат А должен также победить, причем его превосходство над другими кандидатами увеличится. Пересчитав баллы, мы обнаружили, что кандидат А получает 23 балла, кандидат B - 18 баллов, а кандидат C - 19. Кандидат В исключается, а на выборах побе Ка динди $C(12>8)$ ! Кандидат A пр ы при улучшении своих преференций!

Указанные методики, равно как и многие другие, удовлетворяющие требованию маркиза Кондорсе, порождают еще одну парадоксальную ситуацию. Предположим, что в пятом примере проголосовали не 19 человек, а 22, все три дополнительных избирателя являются сторонниками кандидата А. В их бюллетенях установлено следующее соотношение: A>C>B. Казалось бы, кандидат А также должен победить, причем его преимущество должно увеличиться (в этом случае у него почти половина первых голосов: 11 из 23). Так, по методу Болдуина, кандидата А теперь 26 баллов, у В - 21 балл, у С - 22 балда. Кандидат B исклочаетсл, а кендида С побека Кат на внборах $(12>11)$ ! Ка мди А проиграл, набрав боль проитрл, набрав больш дополнительных первых гллосов!! В В силу этото возникае абсур днал силуация избратель вынужден отказаться от участия в выборах, чтобы не ухудшить пол жение своего кандидата (парадокс неучастия no-show paradox) [18]. Считается, что этот парадокс является следствием нарушения критерия участия (participation criterion).

Указанные методики не соответствуют и другим критериям, выработанным Дугласом Вудаллом (в первую очередь, критериям laterno-harm и later-no-help). Смысл в том, что изменение преференций последнего в рейтинге кандидата не должно привести к поражению лидера (later-no-harm) и не должно помочь гандидату, юоторий зая) и не доा er-no-help) [18] . Продемонстрируем эти несо -

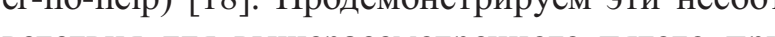
весл дл вы мера, используя правила ВTR-IRV. Итак, каңдидат А имеет 8 первых голосов, кандидат В the Borda count should be suspended and his/her preferences should be annihilated. In this case, if there are only three candidates in the election then, using the language of sport, one can say that the suspended candidate goes straight to the final. After that recount of the remaining candidates' votes according to the Borda count takes place and the one having the most points is suspended and directed to the final round of the election. Then the suspended candidates are reinstated and the final round takes place, and the votes are recounted again according to the Borda count [13]. Apparently, when the number of candidates is large, much more transitional rounds (semi-finals, quarter-finals, etc.) have to be held, with the quantity of operations performed exponentially increasing!

Thus, in the first Condorcet example candidate $B$ should be suspended and sent to the final, candidate $\mathrm{C}$ beats candidate $\mathrm{A}(35>25)$ but is beaten by candidate $\mathrm{B}$ in the final $(42>18)$.

In order to solve the Condorcet paradox, Rob le Grand and Ian Cock have introduced slight changes into the alternative vote method for elections in a single-member district and a multi-member one respectively $[13 ; 18]$. The idea is that the eliminated candidate is determined not through the number of first votes obtained but in a hypothetical "consolation" round where candidates receiving the fewest first votes take part. This method is called BTR-IRV (Bottom Two Ranks - Instant-Runoff Voting). This method resolves the Condorcet paradox in the positive way pronouncing candidate $\mathrm{C}$ the winner. And in terms of the number of first votes received the worst candidates are B (19 votes) and C (18 votes). As it has already been said, the priority in this pair is given to candidate $\mathrm{B}(42>18)$, so candidate $\mathrm{C}$ is pronounced the worst and all his/her votes are passed to candidate A (11 additional votes) and candidate B ( 7 additional votes). Therefore, candidate $\mathrm{A}$ is pronounced the winner.

This article is not aimed at the analysis of the disadvantages of all these methods. Nevertheless, one main drawback should be mentioned here, which is the violation of the monotony rule (mathematician Douglas Woodall named this rule "mono-raise") [18]. In other words, the application of the algorithm may lead to the situation when the change of the winner's preferences for the best (e. g. when the second preferences are changed for the first ones) can result in his/her loss. Let us consider a very typical example which is going to be the fifth: 8 citizens think that $\mathrm{A}>\mathrm{B}>\mathrm{C}, 4$ people decided that $\mathrm{C}>\mathrm{A}>\mathrm{B}, 5$ voters made the following choice $\mathrm{B}>\mathrm{C}>\mathrm{A}$, and finally, 3 voters suppose that $\mathrm{C}>\mathrm{B}>\mathrm{A}$. Thus, according to the Baldwin method candidate A has 20 points, $\mathrm{B}-21$, and $\mathrm{C}$

19 points. Candidate $\mathrm{C}$ is eliminated according to the Borda count as having the fewest points. In the pair $\mathrm{A}$ and $\mathrm{B}$, the priority is given to $\mathrm{A}(12>8)$ and so candidate $\mathrm{A}$ wins the mandate.

Now let us slightly alter the example. Suppose that the three voters whose opinion was $\mathrm{C}>\mathrm{B}>\mathrm{A}$ changed it into $\mathrm{C}>\mathrm{A}>\mathrm{B}$. Seemingly, candidate $\mathrm{A}$ is to win even with a bigger advantage over other candidates. But having recounted the votes, we found out that candidate $\mathrm{A}$ would receive 23 points, $\mathrm{B}-18$ and $\mathrm{C}-19$. Candidate $\mathrm{B}$ is eliminated an candidate $\mathrm{C}$ wins the election $(12>8)$ ! In other words, candidate A lost the election having improved his preferences!

The above mentioned methods, like many other ones meeting the Condorcet requirement, give rise to one more paradoxical situation. Assume that in the fifth example the number of voters was not 19 but 22, with three additional voters being candidate A's supporters. Their ballot papers reveal the following ratio: A $>C>B$. Seemingly, candidate A is bound to win and his/her advantage over other candidates is supposed to increase (in this cas he/she has almost half of first votes: 11 out of 23). Thus, according to the Baldwin method, candidate A receives 26 points, $B-21$ and $C-22$ points. Candidate $\mathrm{B}$ is eliminated and candidate $\mathrm{C}$ wins the election (12>11)! Candidate A lost having received more additional first votes!!! As a consequence, an absurd situation occurs when a voter has to withdraw from taking part in the election in order not to worsen his/her preferable candidate's situation (this is so called "no-show paradox") [18]. This paradox is considered to be the result of violation of the participation criterion

The above methods also do not meet other criteria developed by Douglas Woodall (in the firs place "later-no-harm" and "later-no-help criteria") The thing is that change in preferences of the lowest-ranked candidate should not lead to the leader' defeat (later-no harm) and should not help the candidate in the position higher than his/her one to win the election (later-no help) [18]. Let us consider these mismatches on the above fifth example applying BTR-IRV rules. So, candidate A received 8 first votes, candidate $B-4$, candidate $C-7$. Among the 
следних двух кандидатов приоритет имеет В

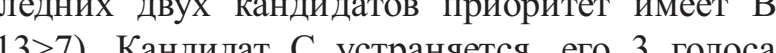
(13>7). Кандидаг С устраняется, его 3 голоса (12 - К А, по19). р). Телерь ирдиололим, что все четыре избирателя, которые голосовали за соотношение $\mathrm{C}>\mathrm{A}>\mathrm{B}$, поменяют свои предпочтения на $\mathrm{C}>\mathrm{B}>\mathrm{A}$ (т. е. первый голос оставят неизменным). Это полностью меняет результат выборов. Также в этом случае кандидат В побеждает С в «утешительном» раунде, кандидат С устраняется, но все 7 голосов переходят... к кандидату В, который и признается победителем (12 голосов из 19)!

Как выяснилось, методика BTR-IRV, как и многие другие, может привести к ситуации, которую можно назвать «парадоксом победы темной лошадки». Приведем следуюший, шестой, пример. Предположим, на выборах участуют три го. Пр

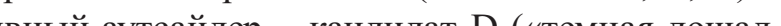
вн). Изб аиде - кандидат D («омная лошадла). Нзбиратели знало о примерно равных шансах кандидагов А, В и С на победу. Поэтому они, голосуя за свои избранников, сознательно занижают рейтинги оппонентов и повышают рейтинг кандидата $\mathrm{D}$, который, по их мнению, изначально не имеет никаких шансов на победу математики называет это явление «патологией победы темной лошадки в условиях участия 3 и более кандидатов» - dark horse wins 3+-way race или, кратко, DH3 pathology) [18]. Предположим, 4 человека установили следующее соответствие: $\mathrm{A}>\mathrm{D}>\mathrm{B}>\mathrm{C} .4$ человека решили, что $\mathrm{A}>\mathrm{D}>\mathrm{C}>\mathrm{B}$. 3 человека посчитали, что $\mathrm{B}>\mathrm{D}>\mathrm{C}>\mathrm{A}$. Также 3 избирателя уверены, что $\mathrm{B}>\mathrm{D}>\mathrm{A}>\mathrm{C}$. Два избирателя считают, что $\mathrm{C}>\mathrm{D}>\mathrm{A}>\mathrm{B}$. Наноне 2 че

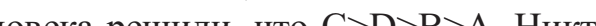
ग (y A $-8, \mathrm{~B}-6, \mathrm{C}-4, \mathrm{D}-0)$. B осов (у A - 8, B - 6, C - 4, D - 0). B паре кандидатов С и D приоритет имеет D (14>8). Следовательно, кандидат С устраняется, его голоса переходят к D (A - 8 голосов, В - 6 голосов, D 4 голоса). $\mathrm{B}$ паре $\mathrm{B}$ и $\mathrm{D}$ приоритет также имеет $\mathrm{D}(12>6)$. Следовательно, необходимо устранить кандидата В, его 6 голосов переходят к D, который побеждает с абсолютным числом голосов (10 из 18). В итоге, победил кандидат $\mathrm{D}$, который, будучи явным аутсайдером, име ет ноль первых голосов! Подчеркнем, никто из избирателей не желал его победы! Отметим, что такой кандидат будет признаваться победитепен и по критерию Кондорсе! Скажем, если бв шровой-

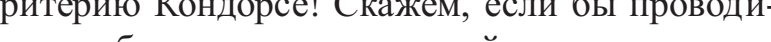
баль выборы по традицион ей системе альтерқан кандидаг А. Так, кандидап D устраняетея сразу как обладапель нулевых голосов. Далее, кандиат С исключается, как наихудший, два голоса он отдает кандидату В, а два - кандидату А, который с 10 голосами преодолевает барьер в $50 \%+1$ голос. Такой же исход был бы и в сл учае проведения выборов по мажоритарной сисеме абсолютного большинства в два тура

Следует сказать и о методе СимпсонаКрамера (Minimax Кондорсе метод). Этот алгоритм называют модификацией правила Кондорсе. Победителем должен признаваться кандидат, у которого при парном сравнении значение наибольшего поражения меньше, чем у любого другого кандидата. Говоря более простым яз ыком, в расчет берется количество голосов, кот орое получил победитель в том или ином парном поражении [13]. Повторим, в первом примере кандидат А лучше В $(\mathbf{3 4}>26)$, В лучше C $(\mathbf{4 2}>18)$, С лучше А $(\mathbf{3 5}>25)$. Каждый кандидат проиграл по одной встрече, но кандидат В имсет порахение с наименьним значением (лим

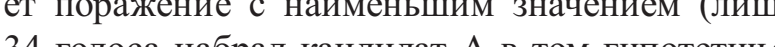
ском туре, в колором кандидат В проиграл). Следовательно, итоговая иерархия буде $\mathrm{B}>\mathrm{A}>\mathrm{C}$. Как считают математики, эта методика плоха тем, что в отдельных случаях победит елем может быть признан кандидат, который я вляется проигравшим по методу Кондорсе. Это может случиться в редких случаях, когда лидеры между собой образуют цикл, а победит кандидат, уступивший всем остальным участникам в парных сравнениях. Приведем седьмой пример. Пусть 1 гражданин решил, что $\mathrm{A}>\mathrm{B}>\mathrm{C}>\mathrm{D}$. Еще один человек уверен, что $\mathrm{A}>\mathrm{B}>\mathrm{D}>\mathrm{C} .3$ избирателя определили, что $\mathrm{B}>\mathrm{C}>\mathrm{A}>\mathrm{D} .1$ гражданин посчитал, что $\mathrm{C}>\mathrm{D}>\mathrm{A}>\mathrm{B}$. Еше 1 избиратель уверен, что $D>A>B>C$.

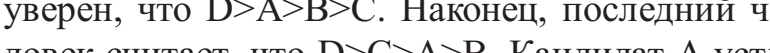
лил в одно сравнеии с кандидат $\mathrm{C}(3<6)$ 1илл в о $\mathrm{B}$ с ср кандидат В уступил в одном сравнении с кандидатом $\mathrm{A}(3<\boldsymbol{6})$, кандидат C уступил в одном сравнении с кандидатом B $(3<6)$. Кандидат D уступи во всех трех парных сравнениях, но с одинако вым счетом (4<5). Следуя традиционным правилам Minimax метода, мы должны признать победителем кандидата $\mathrm{D}$, хотя, если следовать логике маркиза, он победить не может!

Как показали математические расчеть, наиболее удачные методики, которые способнь решить парадокс Кондорсе, разработаны Коуплендом, Тайдеманом, Кемени, Янгом Шульще Один из самых очевидных способо решить парадокс Кондорсе - метод Коупледа. Счите пея, что первоначальн эту систеиу

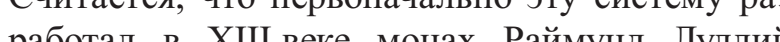

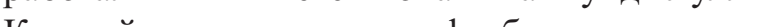
Каждый, кто увлекается фугболом, наверняка знает, каким образом распределяются места в
чемпионате России. Турнирная таблица фут- last two candidates candidate $\mathrm{B}$ has a priority $(13>7)$. Candidate $\mathrm{C}$ is eliminated and his three votes are passed to candidate $\mathrm{B}$ and four votes - to candidate $\mathrm{A}$, with the latter being pronounced the winner (12 votes out of 19). Now let us assume that all the four voters whose opinion was $C>A>B$ would change the first vote $w$ would completely change the result of the election! In this case, candidate $\mathrm{B}$ beats candidate $\mathrm{C}$ in the consolation round so candidate $\mathrm{C}$ is eliminated but all 7 votes are passed ... to candidate $B$, who is pronounced the winner (12 votes out of 19)!

As it turned out, BTR-IRV, like many other methods, can bring a so called dark horse candidate to win. Let us consider the sixth example. Suppose there are three favorites (candidates A, B, and C) and an obvious outsider, candidate D (a dark horse candidate). Voters are aware of the fact that candidates $\mathrm{A}, \mathrm{B}$ and $\mathrm{C}$ have almost equal chances to win the election. Thus, giving their votes to their favorite candidates they deliberately make the opponents' ratings lower and that of candidate $\mathrm{D}$ - higher having in mind that he has no chances to win (in mathematics this phenomenon is called "dark horse wins 3+-way race" or DH3 pathology) [18]. Let 4 people think that $\mathrm{A}>\mathrm{D}>\mathrm{B}>\mathrm{C} ; 4$ voters believe that $\mathrm{A}>\mathrm{D}>\mathrm{C}>\mathrm{B} ; 3$ people decided that $\mathrm{B}>\mathrm{D}>\mathrm{C}>\mathrm{A}$; 3 citizens voted like this $B>D>A>C$; 2 voters' opinion is $\mathrm{C}>\mathrm{D}>\mathrm{A}>\mathrm{B}$; and two people think that $\mathrm{C}>\mathrm{D}>\mathrm{B}>\mathrm{A}$. None of the candidates won the absolute majority of votes (A has $8, B-6, C-4, D-0$ ). In the pair $\mathrm{C}$ and $\mathrm{D}$ the priority is owned by $\mathrm{D}$ $(14>8)$, so candidate $\mathrm{C}$ is eliminated and his votes are passed to candidate $\mathrm{D}$ (A has 8 votes, $\mathrm{B}-6, \mathrm{D}$ 4). In the pair $B$ and $D$ the priority is owned by $D$ again $(12>6)$, so candidate $B$ has to be eliminated and his 6 votes are given to $\mathrm{D}$, who is to win having the absolute majority (10 out of 18). Finally, the candidate $\mathrm{D}$, being an obvious outsider and having no first votes at all, will win the election! And it has to be emphasized that none of the voters wanted him to win! Such a candidate will be pronounced the winner according to the Condorcet criterion as well! If the election was held according to the traditional alternative voting system, candidate A would win it since candidate D would be immediately eliminated as having no first votes. Then candidate $\mathrm{C}$ would be eliminated as the worst one giving two of his votes to candidate $\mathrm{B}$ and two - to candidate A, who, receiving 10 votes, obtains $50 \%+1$ vote Applying the two-round majoritarian system at the election would have the same result.

One more method worth mentioning is that of Simpson-Kramer (Minimax Condorcet method). This algorithm is considered to be a modification to Condorcet method. That candidate should be pronounced the winner who has the least loss valu when comparing pairs. In other words, the number of votes received by the winner in the pair defeat is taken into consideration [13]. In the first example, the situation is as follows: $\mathrm{A}$ is better than $\mathrm{B}$ $(\mathbf{3 4}>26)$, B is better than C $(\mathbf{4 2}>18), C$ is better than A (35 $>25)$. Each candidate lost one pair competition but candidate $\mathrm{B}$ has the least loss value (candidate A received only 34 votes in the hypothetical round lost by candidate $\mathrm{B}$ ). Thus, the final hierarchy will be as follows: $B>A>C$. In terms of mathematics, this method is not perfect as in particula cases the candidate who would lose the election according to Condorcet can be pronounced the winner. It may occur in those rare cases when the leaders' positions form a cycle and the candidate who lost in all pair comparisons will win. Let us consider one more example, the seventh one. One citizen's opinion is $\mathrm{A}>\mathrm{B}>\mathrm{C}>\mathrm{D}$, another person thinks that $\mathrm{A}>\mathrm{B}>\mathrm{D}>\mathrm{C}, 3$ voters decided that $\mathrm{B}>\mathrm{C}>\mathrm{A}>\mathrm{D}$, and 1 voter believes that $\mathrm{C}>\mathrm{D}>\mathrm{A}>\mathrm{B}$, person expressed the following opinion $D>A>B>C$ finally, 1 voter thinks that $\mathrm{D}>\mathrm{C}>\mathrm{A}>\mathrm{B}$. So candidate A lost one competition with candidate $\mathrm{C}(3<\mathbf{6})$ candidate $\mathrm{B}$ lost one competition with candidate $\mathrm{A}$ $(3<6)$; candidate $\mathrm{C}$ lost one competition with candidate B $(3<6)$. Candidate D lost all the three pai competitions but with the same results $(\mathbf{4}<\mathbf{5})$. An if to follow the traditional Minimax method, candidate $D$ is to be pronounced the winner, although, following Condorcet this candidate cannot win!

As mathematical calculations show, some Asthe the Condorcet paradox were developed by Copeland, Tideman, Kemeny, Young, and Shulze. One of the most obvious was suggested by Copeland. This system is believed to have been originally developed in the $13^{\text {th }}$ century by the Majorcan philosopher Ramon Llull. Those interested in football are likely to know how places in the Russian championship are tabulated. The points the teams score are shown in 
больных команд, в которых отражены очки команд, набранные в личных встречах, - это и есть графическое отображение метода Коупленда. Смысл метода Коупленда прост: победитель это лицо, которое имеет наибольшее колич ество побед при гипотетическом парном сравн ении с другими кандидатами [3, с. 52]. Победа означает, что личный счет кандидата увеличивается на 1 балл, поражение, наоборот, уменьшает рейтинг на балл, ничья не изменяет рейтинга. В другой вариации алгоритма победа означает очко, ничья означает пол-очка, поражение не изменяет счет. В последнем виде методика до сих применяется на шахматных турнирах. Следовательно, если $\mathrm{A}>\mathrm{B}, \mathrm{A}>\mathrm{C}$ и $\mathrm{B}>\mathrm{C}$, то кандидат А имеет в рейтинге два балла, кандидат В - один балг, а кандидат $\mathrm{C}$ - ноль очков. Нетрудно заметить, что метод Коупленда - это еше одна вари сще одта вариаun

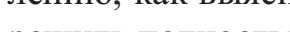
решить полностью парадокс маркиза (табл. 2).
Таблица

Решение парадокса Кондорсе

\begin{tabular}{|c|c|c|c|c|}
\hline Пары & А & В & С & очки \\
\hline A & & 1 & 0 & 1 \\
\hline B & 0 & & 1 & 1 \\
\hline C & 1 & 0 & & 1 \\
\hline
\end{tabular}

Различные ученые предлагали дополнительные правила, чтобы преодолеть такую ничейную ные правила, чтобы преодолеть такую ничейную зовать метод Борда и др.). В основном, критика зовать метод Борда и др.). В основном, критика этого алгоритма заключается в том, что здесь полностью обезличивается ценность той или иной победы, как это и имеет место, скажем, при любом спортивном соревновании, в котором проводится групповой турнир. Именно по этой причине были введены матчи за мировую шахматную корону и отменен групповой турнир.

Парадокс Кондорсе положительно решается с помощью алгоритма Тайдемана (метод ранжированных пар). Он весьма прост и напоминает метод Кондорсе. Сначала необходимо сост а-

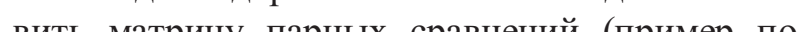
вит й рицу перных срав . Затем мы должны опрделит наибольшие значения побед в парных соопветствиях всех кандидатов и отобрать те, которые образуют суждения. Именно такую работу в XVIII веке проделал маркиз Кондорсе.

Затем нужно ранжировать пары суждений, учитывая значение победы. Далее, двигаясь по полученному списку сверху вниз, мы графически фиксируем последовательность кандидатов.
При обнаружении цикла в последовательности она устраняется [19, p. 45].

Напомним, что, проанализировав матрицу сравнений, маркиз решил, что кандидат А лучше В (34>26), кандидат В лучше C (42>18), кандидат С лучше А $(\mathbf{3 5}>25)$. Количественное значение побед выделено жирным шрифтом. Ранжируем пары и получаем следующую последовательность: на первом месте находится пара $\mathrm{B}>\mathrm{C}$, затем $\mathrm{C}>\mathrm{A}$, а после $\mathrm{A}>\mathrm{B}$

Первые две пары суждений мы графически фиксируем. Последняя пара создает цикл, именно ее мы и устраняем. В итоге, В $>\mathrm{C}>\mathrm{A}$. Кандидат В признается победителем (рис. 2).

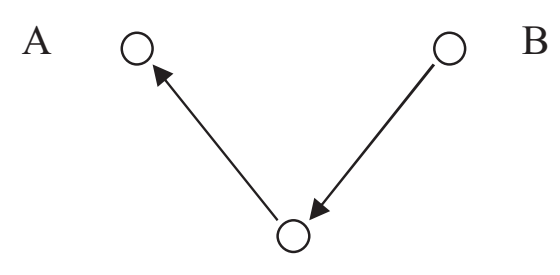

C
Рис. 2. Графическое отображение решения парадокса Кондорсе методом Тайдемана

Алгоритм Тайдемана прост и элегантен, однако он критикуется за то, что победителем может быть признан кандидат, одержавший лишь одну победу в парных сравнения, но с наибольодну победу в

Метод Кемени-Янга гораздо сложнее. Сначала необходимо составить матрицу, в которо будет отражены результаты парных сра внени кандидатов. Затем методом перебора определ яется комбинация соответствий с наибольшей суммой значений побед $[20$, р. 58$]$. В первом примере маркиза всего существует 6 различных комбинаций: $\mathrm{A}>\mathrm{B}>\mathrm{C}, \mathrm{A}>\mathrm{C}>\mathrm{B}, \mathrm{B}>\mathrm{A}>\mathrm{C}, \mathrm{B}>\mathrm{C}>\mathrm{A}$ $\mathrm{C}>\mathrm{A}>\mathrm{B}, \mathrm{C}>\mathrm{B}>\mathrm{A}$. Для дальнейшего решения нам потребуются данные из матрицы сравнений (табл. 1). Так, для комбинации $\mathrm{A}>\mathrm{B}>\mathrm{C}$ (т. е. $\mathrm{A}>\mathrm{B}, \mathrm{A}>\mathrm{C}$ и $\mathrm{B}>\mathrm{C})$ сумма равна $101(34+25+42)$ для комбинации $\mathrm{A}>\mathrm{C}>\mathrm{B}$ сумма равна 77 $(34+25+18)$, дея комбинации $\mathrm{B}>\mathrm{A}>\mathrm{C}$ сумма (34 $93(26+42+25)$, (103) $(26+42+35)$, , ма равна 103 (26+42+35), для комбинации C $>\mathrm{A}>\mathrm{B}$ сумма равна $87(35+18+34)$, наконец, для комбинации С $>\mathrm{B}>\mathrm{A}$ сумма равна 79 $(35+18+26)$. Наибольшая сумма принадлежит соответствию $\mathrm{B}>\mathrm{C}>\mathrm{A}$, следовательно, кандидат В признается победителем. Нетрудно заметить, что при участии в выборах 10 и более кандидатов количество выполняемых операций будет астрономически большим. По сути, метод Ке- the tournament bracket, which is a graphical representation of the Copeland method. The idea behind the method is simple: the winner is the one who has the most winnings when hypothetically compared to other candidates [3, p. 52]. The winning means that the candidate's personal score increases by one point while the loss decreases the rating by one point and a tie game does not change the candidate's position. There is another variation of this algorithm where a tie game brings half a point and the loss does not influence the number of points. The latter is still applied during chess tournaments. Consequently, if $\mathrm{A}>\mathrm{B}, \mathrm{A}>\mathrm{C}$, and $\mathrm{B}>\mathrm{C}$, candidate $\mathrm{A}$ has two points, candidate $\mathrm{B}$ has one point, and candidate $\mathrm{C}$ has none. It is obvious that the Copeland method is one more variation of the Condorcet method. Unfortunately, this algorithm proved unable to fully resolve the Condorcet paradox.

Table 2

The Condorcet paradox solution by the Copeland method

\begin{tabular}{|l|c|c|c|c|}
\hline & A & B & C & points \\
\hline A & & 1 & 0 & 1 \\
\hline B & 0 & & 1 & 1 \\
\hline C & 1 & 0 & & 1 \\
\hline
\end{tabular}

Some additional rules have been suggested by different scientists in order to overcome this tied situation (e.g. Black insists on the use of the Borda count, etc.). Basically the given algorithm is criticized for the fact that any winning gets impersonal and so loses its value as it happens at a sport competition with a group stage. And this was the reason why a group stage in chess competitions was abandoned and matches for the world chess crown were introduced instead.

The Condorcet paradox is positively solved by the Tideman algorithm (method of ranked pairs). It is simple enough and resembles the Condorcet method. First, a matrix of pairwise comparisons is to be obtained (see Table 1); after that the highest winning values in these comparisons should be determined and those forming sentences have to be selected. This is what Marquis Condorcet did in the $18^{\text {th }}$ century.

Then the pairs of sentences have to be ranked with the account of the winning value. After that, following the list obtained from up to down we can graphically represent the sequence of candidates. If the sequence appears to have a cycle then this sequence is eliminated [19, p. 45]

As it was mentioned earlier, having analyzed the matrix of comparisons Condorcet decided that candidate $\mathrm{A}$ is better than $\mathrm{B}(\mathbf{3 4}>26)$, candidate $\mathrm{B}$ is better than $\mathrm{C}(\mathbf{4 2}>18)$, candidate $\mathrm{C}$ is better than $\mathrm{A}$ $(\mathbf{3 5}>25)$. The winning values are in bold. Ranking of the pairs will result in the following subsequence: pair $\mathrm{B}>\mathrm{C}$ is on the first place followed by $\mathrm{C}>\mathrm{A}$ and finally $\mathrm{A}>\mathrm{B}$.

The first two pairs of sentences are graphically represented. The latter pair creates a cycle so has to be eliminated. So B $>C>A$, and candidate B is pronounced the winner.

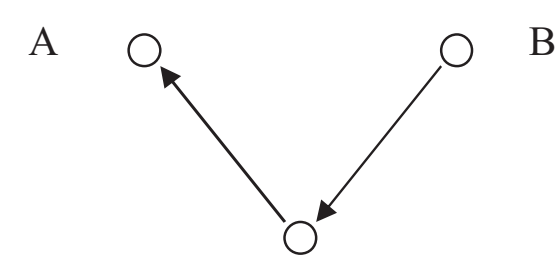

$\mathrm{C}$

Fig.1. Graphic representation of the Condorcet paradox solution by the Tideman method

The Tideman method is simple and smart However, it is criticized for the fact that the candidate having only one winning in pairwise comparisons, although with the highest score, might win.

Far more complicated is the Kemeny-Young method. First of all, it is necessary to obtain the matrix to present the results of the candidates pairwise comparisons. After that, an enumerative technique is applied in order to determine the combination of matches with the largest sum of winning values $[20$, p. 58]. In the first Condorcet example, there are 6 different combinations: $\mathrm{A}>\mathrm{B}>\mathrm{C}$, $\mathrm{A}>\mathrm{C}>\mathrm{B}, \mathrm{B}>\mathrm{A}>\mathrm{C}, \mathrm{B}>\mathrm{C}>\mathrm{A}, \mathrm{C}>\mathrm{A}>\mathrm{B}, \mathrm{C}>\mathrm{B}>\mathrm{A}$. For solution, one will need the data from the matrix of comparisons (see Table 1). Thus, for the comb ina tion $\mathrm{A}>\mathrm{B}>\mathrm{C}$ (i.e. $\mathrm{A}>\mathrm{B}, \mathrm{A}>\mathrm{C}$ and $\mathrm{B}>\mathrm{C}$ ) the total is $101(26+42+35)$; for the combination $A>C>B$ the total is $77(34+25+18)$; for the combination $B>A>C$ the total is $93(26+42+25)$; for the combination $\mathrm{B}>\mathrm{C}>\mathrm{A}$ the total is $\mathbf{1 0 3}(26+42+35)$; for the combination $\mathrm{C}>\mathrm{A}>\mathrm{B}$ the total is $79(35+18+26)$. The largest total belongs to the combination $\mathrm{B}>\mathrm{C}>\mathrm{A}$, therefore candidate $\mathrm{B}$ is to be pronounced the winner. Apparently, if more than ten candidates take part in the election, the quantity of operations to be performed will be extremely large. In fact, the 
мени-Янга чем-то напоминает алгоритм Тайдемана и критикуется по тем же основаниям.

В XXI веке у математиков все большее зн ачение получает методика Шульце (метод ко свенных путей). Выражаясь простым языком, если при парном сравнении кандидат А побеждает Б, а Б - С, а С - Д, то мы можем говорить, что есть путь от кандидата А к Д. Чем больше олосующих предпочитаю иервог кандидата второму, тем убедительнее его победа. Силой пути будет являться слабейшая парная победа кандидата в этой последовательности (ее еще называют критическим звеном). Кандидат А побеждает кандидата В косвенно, если выполняется любое из двух условий: сила критического звена от А к В больше, чем сила критического звена от В к А; сушествует путь от А к В, а пути от В к А нет.

Правило Шульце соответствует требованию транзитивности, следовательно, если А побеждает В косвенно, а сам В косвенно побеждает C, и и А косвенно побеждает C $[17$, p. 270]. Эта методика нам представляется наиболее логичой, в отличие от всех вышеперечисленных.

В настоящий момент этот алгоритм испол ьзуется при проведении внутрипартийных выборов пиратских партий многих стран Европы, а также голосований в сети Интернет (например, таким алгоритмом избираются кураторы Википедии). Вручную произвести итоговое ранжирование кандидатов можно лишь при небольшом числе кандидатов, потратив на это весьма значительное время.

Итак, используем метод Шульце в первом примере, демонстрирующем парадокс Кондорримере, демонстрирующем парадокс Кондорс.. Напомним, что в данном примере А лучше В (34>26), B луте С (42>18), C лучше A (35>25). Значения побед в этих парных сравнениях фикиируются на схеме, которую маркиз Кондорс отобразил еще в XVIII веке.

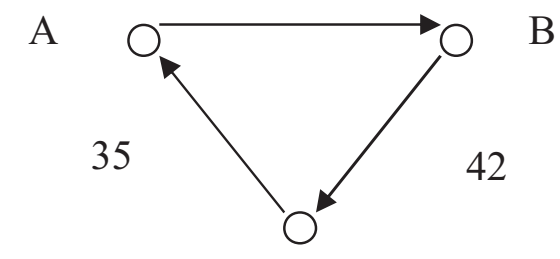

C

Рис. 3. Силы путей между кандидатами

Далее, мы должны выявить силу пути от каждого кандидата к каждому (сила пути будет равняться наименьшему значению в цепочке пути, т. е. критическому звену). Так, от кандидата А сила пути к В равна 34 (прямой путь A>B), сила косвенного пути к С также равна 34 (сила пути $\mathrm{A}>\mathrm{B}$ равна 34 , существует сила пути $\mathrm{B}>\mathrm{C}$ со значением 42 , которая игнорируется). Показатель критического звена нами выделен жирным шрифтом. От кандидата В сила косвенного пути к А равна 35 (сила пути $\mathrm{B}>\mathrm{C}$ со значением 42 игнорируется, сила пути $\mathrm{C}>\mathrm{A}$ составляет 35), сила прямого пути к кандидату C равна 42 (В $>$ C). От кандидата С сила прямого пути А равна $35(\mathrm{C}>\mathrm{A})$, сила косвенного пути к равна 34 (сила пути $\mathrm{C}>\mathrm{A}$ со значением 35 игнорируется, сила пути $\mathrm{A}>\mathrm{B}$ равна 34 ) (рис. 3 ).

Затем мы должны составить матрицу силь(табл. 3).

Матрица сильнейших путей

\begin{tabular}{|l|c|c|c|}
\hline \multicolumn{1}{|c|}{ Пары } & А & B & C \\
\hline Путь от А к... & & 34 & 34 \\
\hline Путь от В к... & $\mathbf{3 5}$ & & $\mathbf{4 2}$ \\
\hline Путь от С к... & $\mathbf{3 5}$ & 34 & \\
\hline
\end{tabular}

Очевидно, что путь от кандидата В к А имебольшую силу, чем путь от А к В $(\mathbf{3 5}>34)$. Путь от В к С также имеет большую силу, чем путь от С к В (42>34). Наконец, путь от С к А имеет большую силу, чем путь от А к С (35>34). Таким образом, иерархия кандидатов в первом примере следующая: $\mathrm{B}>\mathrm{C}>\mathrm{A}$

В рассмотренном примере участвовали лишь три кандидата, был только один путь (прямой или косвенный) от кандидата к кандидату. Например, при участии 10 и более кандидатов возникает гигантское количество путей от кандидата к кандидату. В этом случае в матрицу сравнения путей будут вноситься зночения сильейних путей (т. е. путей с напботения силье задану может решй только к Солалосов избирателей.

Согласно методу Шульце, если в первом примере маркиза будет избираться 2 кандидата, избранными должны стать В и С. Но справедливо ли это? Кандидат А набрал количество гол осов свыше квоты Друпа. Так, если предположить, что в этом округе все три кандидата представляли разные партии, то окажется, что партия кандидата А с $38 \%$ голосов вообще осталась без мандата! Это объясняется тем, что менд Шульце соответствует правилу

Многие ученые в России и за рубежом считают метод Шульце практически идеальным.
Kemeny-Young method looks a little like the Tideman method and is criticized for the same reasons.

In the $21^{\text {st }}$ century, the Shulze method (Beatpath method) is becoming more popular among mathematicians. If after a pairwise comparison candidate A beats candidate B, B beats $\mathrm{C}$, and $\mathrm{C}$ beats $\mathrm{D}$, one can say that there is a path from candidate $\mathrm{A}$ to candidate $\mathrm{D}$. The more voters prefer the first candidate to the second one, the stronger his winning is. The weakest pairwise winning in the sequence is called the strength of the path. Candidate $\mathrm{A}$ beats candidate $\mathrm{B}$ indirectly if any of the conditions is fulfilled: either the strength of the critical link from $A$ to $B$ is more than that from $B$ to $A$, or there is a path from A to B but no from B to A.

The Schulze method matches the requirements of transitivity, so if A beats B indirectly and $\mathrm{B}$ in his/her turn indirectly beats $\mathrm{C}$, then $\mathrm{A}$ also beats $C$ indirectly [17, p. 270]. This method, compared to those mentioned above, appears to be the most logical

Currently this algorithm is used when holding intraparty elections of Pirate Parties in many European countries as well as at some Internet polling (e. g. Wikipedia curators are chosen by this algorithm). Manual final ranking of candidates is only possible if the number of candidates is relatively small but even though it would take considerable time.

Thus, let us apply the Schulze method to the first example representing the Condorcet Paradox. In the example $A$ is better than $B(\mathbf{3 4}>26)$, candidate $B$ is better than $C(\mathbf{4 2}>18)$, candidate $C$ is better than $\mathrm{A}(\mathbf{3 5}>25)$. The values of winnings in these pairwise comparisons are represented on the graph plotted by Condorcet in the $18^{\text {th }}$ century.

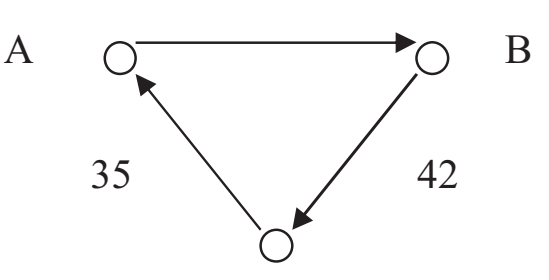

Fig. 3. The path strengths between the candidates

Further, strengths of each path between the candidates have to be determined (path strength is equal to the lowest value on the path, i.e. to the critical link). Thus the strength of the path from candidate $\mathrm{A}$ to candidate $\mathrm{B}$ is 34 (straight path $\mathrm{A}>\mathrm{B}$ ) the strength of the indirect path from $A$ to $C$ is also 34 (the strength of the path $\mathrm{A}>\mathrm{B}$ is $\mathbf{3 4}$, the strength of the path $B>C$ equal 42 is neglected). The value of the critical link in in bold. The strength of the indirect path from $B$ to $A$ is 35 (the strength of the path $B>C$ equal 42 is neglected, the strength of the path $A>B$ is 34).

After that the matrix of the strongest paths between all the candidates is obtained:

The matrix of the strongest paths

\begin{tabular}{|l|c|c|c|}
\hline & A & B & C \\
\hline Path from A to ... & & 34 & 34 \\
\hline Path from B to ... & $\mathbf{3 5}$ & & $\mathbf{4 2}$ \\
\hline Path from C to... & $\mathbf{3 5}$ & 34 & \\
\hline
\end{tabular}

Obviously, the path from candidate B to candidate $\mathrm{A}$ is stronger than from $\mathrm{A}$ to $\mathrm{B}(\mathbf{3 5}>34)$; likewise the path from $\mathrm{B}$ to $\mathrm{C}$ is stronger than that from $\mathrm{C}$ to $\mathrm{B}(\mathbf{4 2}>34)$; finally, the path from $\mathrm{C}$ to $\mathrm{A}$ is stronger than that from A to $C(\mathbf{3 5}>34)$. Thus, the hierarchy of candidates obtained is as follows: $\mathrm{B}>\mathrm{C}>\mathrm{A}$.

In the above example, there were only three candidates and there was only one path between them (direct or indirect). If the number of candidates were 10 and over, there would be a hug number of paths between these. In this case, only the strongest paths (those having the highest values of critical links) should be introduced into the matrix. Such a complicated task can only be solved with the help of computerized vote processing.

According to the Schulze method, if in the firs Condorcet example two candidates are to be elected then these must be candidates B and C. But is that fair? In fact, the number of votes given to candidate A exceeded the Droop quota. And assuming that all the three candidates in this district represent different parties we see that the candidate A's party, having received $38 \%$ of all the votes, is left without a mandate at all! This can be explained by the fact that the Schulze method matches the Condorce rule, not the principle of proportionality.

The Schulze method is considered almost perfect by many scientists both in Russia and abroad. 
Однако это не так. Как и другие методы, соответствующие правилу Кондорсе, он, в частновеси, не уст правилу Кондорсе, он, в мастносл, ,е уст лошадки», парадокса «поражения при получении дополн Иначе говоря, он не соответствует критерию участия, а также критериям later-no-harm и laterno-help [18]. Указанный алгоритм может прим еняться лишь на выборах в одномандатных округаx, а также при определении порядка кандидатов в открытом партийном списке. Следов ательно, его нельзя использовать на выборах в многомандатном округе. Но, как известно, ни одна из пропорциональных систем не может гарантировать равного участия партийных и гарантировать равного
независимых кандидатов.

Мы разработали систему, которая является гибридом BTR-IRV и метода Кумбса. Отличия от метода BTR-IRV заключаются в том, что в «утешительном» раунде должны «участвовать» два кандидата с наибольшими последними предпочтениями. В этом случая данная система, в отличие от метода Кумбса, будет соответств овать критерию Кондорсе. В отличие от системы BTR-IRV, она более склонна к монотонности, но целиком этому принципу все же не соответствует, равно как и все другие системы с выбыванием. Как мы уже сказали, в «утешительном» раунде участвуют два наихудших кандидата по числу последних голосов, следовательно, улучшение преференший лидера лишь в очень редких случаях повлияет на опредение виб редких

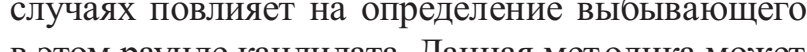
в этом раунде кандидата. Данная методика может применянся на виборах в мнотоманданом

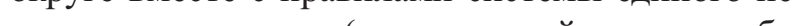
редаваемого голоса (исключаемый кандидат будет определяться в гипотетическом «утешительном» раунде, следовательно, исключается не справедливый результат в четвертом примере)

Так, в примере маркиза Кондорсе наша система победу отдаст кандидату В. Напомним, большинство третьих голосов - у кандидата С (25) и А (24). В парном сравнении кандидат С одерживает победу $(35>25)$ и выходит в финал, в котором уступает кандидату В $(42>18)$. Напомним, система BTR-IRV победу отдавала кандидату А. Мы с таким результатом катег орически не согласны. Кандидат В - меньшее из рически не сола сы трех зол, разраболанная нами сислема берет это правило за основу, но не нарушаст критерия

О

Отметим, что разработанная нами модификация системы BTR-IRV также имеет массу недостатков. Она не решает «парадокса победы темной лошадки», также не соответствует критериям later-no-help и later-no-harm. Но у нее есть важное достоинство - в отличие от методик Шульце и Кемени-Янга, она позволяе стве операций.

\section{Результаты}

Многие преференциальные системы полоительно решают первый парадокс Кондорсе Однако при этом они порождают ряд других парадоксов, поэтому их нельзя называть идеальными. Разумеется, в современной России преференциальные системы вряд ли могут применяться. Можно выделить несколько причин. Одна из них скрывается в психологии избирателей и кандидатов. В силу этого они вряд ли поймут, почему на выборах победителем будет признан кандидат, который вообще не получил ни одного первого голоса. Мы считаем, что обыватели также не поймут, почему при получении дополнительного числа своих первых голосов, прельдуший лидер голосования пронгрывает. Подавлюшее большинство граждан росл.

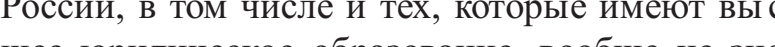
, что такое транзитивность.

У преференциальных систем есть иной существенный недостаток: избирателю неизвес ны критерии ранжирования кандидатов. Кто-то может оценивать честность, кто-то решительность, а кто-то просто чувство юмора. Некоторые избиратели будут использовать эти критерии в совокупности, а другие - по отдельности и пр. Более того, человек - это не число. Лишь число два всегда будет больше единицы, но меньше трех. Но попробуйте оценить качества тех или иных Но попробуйте оценить качества ех ватзио избирательй смогуг определить наилучшего кандидата, а также того, кто займет второе м есто и, в лучшем случае, третье. Мы сомневаемся, что рядовые избиратели смогут решить, кто займет четвертое, пятое, шестое и последующие места: такие кандидаты для них равнозначны. Именно по этой причине ученые модифицировали метод Борда, ограничив избирателя правом выставить лишь три преференции. При этом отметим, что без тотального ранжирования кандидатов в бюллетене падает точность преференциальной системы, в этом случае она де-

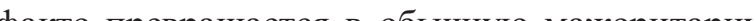
в

Далее, нельзя забывать,

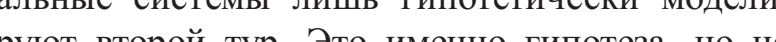

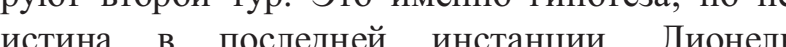
Жоспен, проигравший выборы в 2002 г., мог
However, it is not quite so. Like other methods matching the Condorcet rule, it is unable to resolve the dark horse paradox or add-top failure. In other words, it matches neither the participation criterion nor later-no-harm and later-no-help criteria [18]. The discussed algorithm can be in use only at a single-member district election or when specifying the sequence of candidates in the party ticket. However, none of proportional systems guarantees equal participation of party and independent candidates.

We have developed a system which is a hybrid of BTR-IRV and Coomb's method. The system obtained differs from BTR-IRV in the way that in the consolation round the two candidates having the largest quantity of last preferences must participate. In this case, the system, unlike Coomb's method, will meet the Condorcet criterion. The difference between BTR-IRV and our system is that it does tend to monotony but does not meet this criterion in full, the same way as other systems including elimination. As it has already been mentioned, two candidates recognized the worst by the number of last preferences participate in the consolation round, so the improvement of the leader's preferences would hardly have any effect on the decision which of the candidates should be eliminated in this round. This method can be applied at election in multi-member districts together with the rules of single transferable vote system (the candidate to be eliminated is determined in the hypothetical consolation round so the unfair result shown in the fourth example is out of the question).

Thus, in the Condorcet example according to our system candidate B would be pronounced the winner. As it was said earlier, the majority of third votes belong to candidates $\mathrm{C}$ (25) and A (24). In pairwise comparison candidate $\mathrm{C}$ wins $(35>25)$ and reaches the final where he/she gives way to candidate B $(42>18)$. According to BTR-IRV system the winner is candidate $\mathrm{A}$. We strongly disagree with this result. We suppose candidate $\mathrm{B}$ to be the lesser of three evils and the system we have developed takes it as a bases but does not fail to meet the Condorcet criterion, unlike the Coomb's method.

It should be noted that the modification to the BTR-IRV system we have developed also has quite a number of drawbacks. In fact, it does not resolve the dark horse winning paradox and does not meet later-no-help and later-no-harm criteria. However, it has a significant benefit: in contrast to the Schulze and Kemeny-Young methods it allows for determining results with fewer operations involved.

Results

Many preferential systems positively resolve the first Condorcet paradox. However, they give rise to a number of other paradoxes, so they cannot be considered ideal. Apparently, preferential systems can hardly be applied in modern Russia, and there are several reason for it. One of these lies in psychology of voters and candidates. They are unlikely to understand why the candidate having no first votes at all can be pronounced the winner. They will be unable to understand either why the previous leader of the voting loses after receiving additional number of his first votes. The majority of Russian people, including those having higher legal education, do not have a notion of transitivity.

Preferential systems have one more considerable failing, which is the fact that voters are unaware of the criteria for ranking candidates. Some people tend to evaluate honesty, others evaluate decisiveness, still others - a sense of humor. Moreover, a person is not just a number. Number 2 will always be more than 1 and less than 3 . But it is not so easy to evaluate personal qualities of people, let alone rank these! Apparently, the majority of voters are able to determine the best candidate as well as the one who will be the second and probably the third. But it is really doubtful that common voters could decide who will get the fourth, fifth and subsequent positions; those candidates are similar for them. For this very reason scientists have improved the Borda method allowing voters to express only three preferences. And it should be noted that without total ranking of candidates in the ballot paper the accuracy of preferential system declines and de facto it turns into a majoritarian system with a categorical vote.

In addition, it is important to keep in mind that preferential systems create only hypothetical simulation of the second round. It should be treated as a hypothesis but not as the ultimate truth. Lione Jospin, who lost the presidential election in 2002, 
считать себя истинным президентом, но это не солее чем прелположение. Историн человечества известен случай, гогда всего лиш за одну сва известен случай, кох ос всег лишь за одну ग из царл преврай в в пестулника. Нередко олеблющиеся граждане меняли свои убеждения между первым и вторым турами голосования. Преференциальные системы такой возможности изначально не дают, вводя в аксиому суждения человека, который, может быть, пр инял свое решение лишь в день голосования, знакомясь со списком кандидатов в помещении для голосования. Отметим, что именно такие избиратели в рамках преференциальной системы могут решить исход выборов, неосознанно отдавая предпочтение «темной лошадке». Двухт уровые системы позволят таким избирателям ровые системы позволят таким избирателям

В настояний момент выборы в России ос-

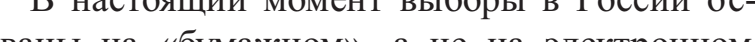
нованы на «бумажном», а не на электронном

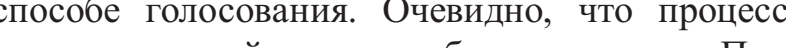
оллосования займет очень большое время. При проведении выборов в единые дни голосования вполне возможны очереди на избирательных участках. Наверное, многие избиратели просто откажутся голосовать, так как у них иссякнет терпение, пока они будут ждать своей очереди к кабине для голосования

Наконец, процесс определения результатов на таких выборах практически немыслим без компьютерной системы обработки голосов. В России бюллетени до сих пор подсчитываются вручную, при этом основная задача членов УИК - это не провести честный полсчет нов УИК - это не провести честный подсчет олосов, а подвести итоги голосования без масематических ошибок в определении установ-

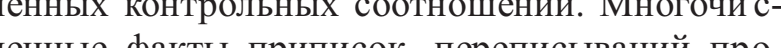
ленные факты приписок, переписываний проТИКов лишь подтве $\mathrm{p}$ -

\section{Выводы}

Мы считаем, что ошибочно рассматривать один парадокс Кондорсе в отрыве от других. Авторы, в основном, пересказывают первый, забывая о втором и третьем. Однако они все заимосвязаны.

Второй парадокс Кондорсе гласит: пусть 1 человек считает, что $\mathrm{A}>\mathrm{B}>\mathrm{C} .1$ человек уверен, что $\mathrm{B}>\mathrm{C}>\mathrm{A}$. Третий решил иначе: $\mathrm{C}>\mathrm{A}>\mathrm{B}$. Следовательно, любое большинство (любые два человека или все) уверено в цикличном абсурдном положении: $\mathrm{A}>\mathrm{B}>\mathrm{C}>\mathrm{A} \ldots$ и и. д. Отметим, что ни один из методов (включая алгоритм Шульше) не может дать положительный ответ на этот парадокс.
Третий парадокс связан с абсурдной ситуацией при принятии закона в парламенте. На втором чтении предложены три поправки к закону. Они частично противоречат друг другу (как и указанные во втором парадоксе суждения). В парламенте есть три крупные фракции, которые эти поправки предложили. Все три поправки принимаются на втором чтении большинством (какие-то две партии сойдутся в своих мнениях), но на третьем, решающем, чтении закон целиком отклоняется.

Долгие годы ученые ломали свои головы над этими парадоксами. Эрроу в 1951 г. заявил, что ни одна из существующих методик голосования не удовлетворяет разработанным им аксиомам принятия социального выбора. Точне сказать, ей соответствует только правило дикт атора. Но сам Эрроу, будучи демократом, отвер это правило, признавая невозможном, оввер бирательную сисему [11, p. 32]

Справедливых избирательных систем нет, равно как нет идеальных законов, идеальных языков, идеальных культур и др. Таким образом, мы не можем говорить о том, что существует какая-то идеальная система с категориальным голосованием, равно как нет ни одной идеальной преференциальной системы. Многие методики имеют достоинства и недостатки, которые проявляются в тех или иных обсто ятельствах.

В государствах с истинно двух - или псевдодвухпартийной системой (многопартийной системой с доминированием только твух партий) использование двухтуровых махоритарнох систе crum ro бах в СIIA и Ве влоле оправдано. На выбо-

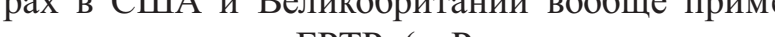
няются системы FРТP (в России их называю методиками относительного большинства), которые, будучи изначально недемократичными, данных условиях не так часто приводят к несправедливым результатам. Чаще всего кандидат получает на выборах свыше 50 \% голосов избирателей, так как участвуют лишь два кандидата, которые реально борются за мандат Даже более того, весьма частым явлением на парламентских выборах в США является отказ от проведения голосования, поскольку зарегистрирован линь один гандидат (он автонатич ески признается победитегем). Наоборот, в дейски признов в дейс лиси Шен пе дики Шулце, например) имее явные преимущесва. Так, ссли бы на втром чении в третьем примере Кондорсе производилось рейтинго- could consider himself a true president but it was merely a prediction. The history of the mankind has seen a case when it took just a week for a person to change from a king into a criminal in the public's eyes. It often happened that those hesitating changed their opinions between the first and second rounds of voting. As for preferential systems, they do not provide such an opportunity because they take as an axiom the judgment of a voter who might have formed it on the very day of the election while looking through the list of the candidates in the polling booth. It should be noted here that these are such voters who subconsciously giving their preferences to a dark horse can turn the beam of the election being held according to a preferential system. Two-round systems allow such voters to realize their mistake and change their mind.

Nowadays elections in the Russian Federation are based on "paper" not electronic system of voting. Obviously, the process takes a great deal of time and causes enormous queues at polling places, which may lead to the situation when voters running out of patience would merely refuse to vote.

Finally, the count of votes at such elections is hardly possible without their computer processing. However, in Russia ballot papers are still processed manually and the main task members of ballot commissions face is not to perform a fair count of votes but to make no mathematical mistakes when determining the control ratio stated. For this argument state many facts such as numerous adscripts and cases of rewriting protocols by Territorial Electoral Commissions.

\section{Conclusions}

We think that considering one Condorcet paradox in isolation from the other ones is wrong. Researches mostly deal with the first one without taking into account the second and the third paradoxes. However, in fact they are interconnected.

The second Condorcet Paradox is as follows. Let one person think that $A>B>C$; another citizen believes that $\mathrm{B}>\mathrm{C}>\mathrm{A}$; and one more person's opinion is that $\mathrm{C}>\mathrm{A}>\mathrm{B}$. Consequently, any majority (any two or all the three persons) gets into a cyclic absurd situation: $\mathrm{A}>\mathrm{B}>\mathrm{C}>\mathrm{A} \ldots$ etc. It should be noted that none of the methods (including the Schulze method) is able to resolve this paradox positively.
The third paradox is connected with the absurd situation that would take place during the adoption of a law in the parliament. During the second reading three amendments to an act were suggested, those being partially contradictory to each other (a well as sentences from the second paradox). Each amendment was suggested by one of the three large parliamentary groups. All the three amendment were adopted at the second reading by the majority (some two of the parties would share their opinions) but at the third, the most crucial, reading the law is completely rejected.

The paradoxes under discussion have been puzzling scientists for many years. In 1951 Joseph Arrow claimed that none of the existing methods of voting satisfies the patterns of social choice he had developed. To be more exact, the only method able to satisfy them is the rule of dictator. However, being a democrat, Arrow rejected this rule himself, accepting the fact of impossibility to develop a really fair electoral system [11, p. 32].

There are no fair electoral systems, as well as there are no perfect laws, perfect languages, perfect cultures, etc. Thus, we cannot speak about a really existing ideal categorical voting system, neither there is an ideal preferential system. Different methods have their own advantages and disadvantages, which become apparent under certain circumstances.

In the states with true two-party or pseudotwo-party systems (multi-party system with th domination of only two parties) the application of two-round majoritarian systems with categorica voting is fairly justified. The USA and Britain apply FPTP systems (in Russia they are called plurality methods), which, although originally nondemocratic, do not result in unfairness as frequently as the other ones. Most often a candidate at the election receives over $50 \%$ of votes as there are usually only two candidates who are likely to win. Moreover, it frequently occurs in the USA that the parliamentary election is abandoned since only one candidate is registered (who is automatically pronounced the winner). On the contrary, in true multi-party countries the use of a preferential system (e. g. the Schulze method) is advantageous. Thus, if at the second reading in the thirc Condorcet example preferential voting had taken 
вое голосование, ни одна из поправок не была бы принята.

Нетрудно заметить, что представительная демократия может существовать без парадоксов Кондорсе только в двухпартийных системах Именно в этом случае не будет возникать третья партия с иной точкой зрения. Все рассмотренные парадоксы Кондорсе связаны именно с этой третьей силой. В условиях участия в выборах лишь двух кандидатов не возникает никакой необходимости в различных математических ухищрениях, преференциальных системах и проч. Если есть лишь две точки зрения во втором примере Кондорсе (например, $\mathrm{A}>\mathrm{B}>\mathrm{C}$ и $\mathrm{C}>\mathrm{A}>\mathrm{B}$ ), то какая-то из них найдет поддержку среди трех и более избирателей.

Если в третьем примере есть две фракции, а не три, парадокс также успешно решается. Именно поэтому США и Великобритания не используют пропорциональную избирательную систему на парламентских выборах, чтобы сохранить существующие псевдодвухпартийные системы.

Недаром самые устойчивые государства в мире имеют псевдодвухпартийные системы. Так, в США свыше 100 партий, но только две из них реально борются за власть. Нечто подобное мы видим в Великобритании, Японии, Индии, Австралии, Канаде и др. Наоборот, Италия, не имеющая двух крупных политических сил, с момента принятия новой Конституции в 1947 г. существует в условиях постоянного правительственного кризиса (за вторую половину XX века в Италии сменилось около шестидесяти габинетов Италис с . В састояний момент в Итабинетов дена уникаль дена унй система, призванная искусственным образом соать две крупные фракции в парламен

В целом, мы считаем, что если полного решения парадоксов Кондорсе не существует, то необходимо создать условия, при которых не будут возникать ситуации, имевшие место во Франции в 2002 г. Разумеется, для этого не нужно запрещать создания маленьких партий, как это имело место в России до 2012 г. Переход на двухтуровую мажоритарную систему абсолютного большинства для формирования парламента также нам кажется необоснованным, поскольку в условиях сушествования четырех крупных партй это приведет к наруше-

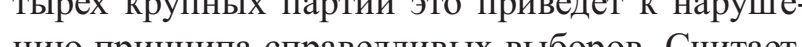
ся, что многие ся, (кумулятивного глосования, единого неперед аваемого голоса, ограниченного вотума и др.), ствуют возникновению двухпартийного парла- мента. При этом учитывают, в той или иной степени, и волю большинства, и волю меньшинства $[10$, c. 400]. Мажоритарные системы последнего свойства лишены. Так, в испанском Сенате существуют две крупные фракции, хотя он избирается по системе ограниченного вотума (избиратель наделяется меньшим количеством голосов, чем избирается депутатов в округе, парти также не выдвигают кандидатов более этого числа). Очевидно, что в этом случае часть парламента изначально квотируется за представителями оппозиции. Независимые и партийные кандидаты на равных условиях борются за мандаты, но при этом результаты отдаленно нап оминают итоги выборов, проводимых по пропорциональной системе (отсюда и название, которое означает, что такие выборы почти пропорциональные). В тех условиях, юогда в парламе те будут сформи рованы де крупны

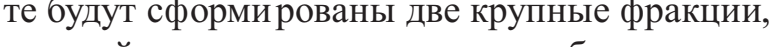
дальнй се лй боротся за влась (они нолучат доступ к медиаи административному ресурсу). Следовательно, в таких государствах на президентских выборах двухтуровая мажоритарная система абсолютн ого большинства вряд ли приведет к казусу, ан алогичному тому, который имел место во Франции в 2002

Государства, напоминающие США или В еликобританию, можно называть псевдодиктат урой. Есть лишь две крупные партии, только они реально борются за власть. Голос за третью партию де-факто означает его недействительность Избирателям приходится голосовать за наимснее худшего из двух основных кандидатов

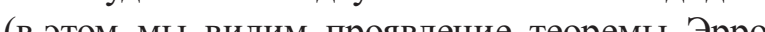
(в э.ом

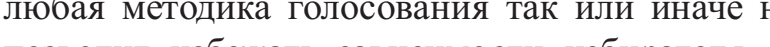

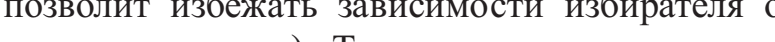
воли дру1 друг друга, правят страной, устраняя все иные всеские силы на своем пути.

Вспомним известное высказывание том, что «демократия - это наихудшая форма правления, не считая остальные». Действительно, демократия в псевдодвухпартийном обществе далеко не идеальна. Но, к сожалению, иного варианта нет и быть не может. Именно в этом и заключается глубинный смысл парадоксов Кондорсе.

\section{Библиографический список}

Белов С. А. Системное правовое регулирование избирательной системы // Российский

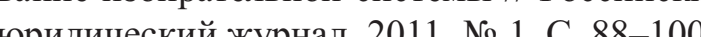
Бердй Берлявскй Л. Г. Сравнительное избирательное прав. М.: Ю. Притформ, 2013. 240 c.

3. Вольский В.И. Процедуры голосования в
малых группах с древнейших времен до place, none of the amendments would have been adopted.

Obviously, representative democracy can exist without the Condorcet paradoxes only in two-party systems. And it is the situation when a third party representing a different opinion would not appear. All the Condorcet paradoxes considered above are connected with this third power. If there are only two candidates taking part in the election, there is no need in any mathematical ingenuity, preferential systems, etc. If in the second Condorcet example there are only two opinions (e.g., $\mathrm{A}>\mathrm{B}>\mathrm{C}$ and $\mathrm{C}>\mathrm{A}>\mathrm{B}$ ), one of them will definitely find support from three or more voters.

If in the third example there are two parliamentary groups instead of three, the paradox is also resolved successfully. That is why the proportional voting system is not used in the USA and Britain at parliamentary elections - in order to retain the existing pseudo-two-party systems. This explains why the world's most stable countries practice pseudotwo-party systems. For example, in the USA there are more than 100 parties but only two of them actually struggle for power. Similar situations can be observed in Great Britain, Japan, India, Australia, Canada, etc. On the contrary, Italy, which has not had two major political powers since the new Constitution was adopted in 1947, is constantly experiencing a governmental crisis (just during the second half of the $20^{\text {th }}$ century Italy saw about sixty cabinets). Currently a unique two-round proportional system has been introduced in the country, which is aimed at artificial creation of two large groups in the parliament.

Generally, we think that if there is no complete solution to the Condorcet paradoxes, the conditions are to be created under which such situations as that of 2002 in France will not occur. Clearly, formation of smaller parties should not be banned as it had taken place in Russia up to 2012. We find unjustified the transition to a two-round absolute majority system since with the existing four large parties it may lead to the violation of the fair election principle. Many semi-proportional voting systems (cumulative voting, single transferable vote system, limited voting), the same as majoritarian systems, are thought to contribute to the formation of the two-party parliament. In this case, both the majority's and minority's opinions are taken into account [10, p. 400]. Majoritarian systems, however, do not possess this feature. For example, there are two large groups in the Spanish Senate although its members are elected by the limited voting system (voters have fewer votes than there are deputy positions available, parties also do not propose more candidates than this number). Apparently, a part of the parliament is quoted by the opposition representatives. Independent and party candidates are i the same conditions in their struggle for power but the results slightly resemble those of the proportional system election. In the situation when two large parties are present in the parliament, only these parties will really struggle for power (they will get access to media- and administrative resources). Consequently, at presidential elections in such countries the absolute majority system is unlikely to result in the case similar to the one that took place in France in 2002.

Countries with the systems like in the USA or Great Britain can be named pseudo-dictatorships. There are only two large parties and only these are really struggling for power. A vote given to some third party is invalid de facto. Electorate has to vote for the lesser bad candidate out of two major ones (we see this fact as the demonstration of Arrow's theorem according to which any voting system would not let a voter avoid his/her dependency on other people's will). Only two parties, changing each other, run a country and push aside all political forces emerging on their way.

There is a well-known saying by Richard M. Langworth: "Democracy is the worst form of government, except for all the others". Truly, democracy in a pseudo-two-party state is far from perfect. Moreover, it can be appalling and disgusting. Unfortunately, there is no and cannot be another variant. Therein lies the deep meaning of the Condorcet paradoxes.

\section{References}

Belov S. A Sistemnoe pravovoe regulirovanie izbiratel'noy sistemy [System Legal Regulation of Electoral System]. Rossiyskiy yuridicheskiy zhurnal - Russian Juridical Journal. 2011. Issue 1. Pp. 88-100. (In Russ.)

2. Berlyavskiy L. G. Sravnitel'noe izbiratel'noe pravo [Comparative Suffrage]. Moscow, 2013. 240 p. (In Russ.)

3. Vol'skiy V. I. Protsedury golosovaniya v malykh gruppakh $s$ drevneyshikh vremen do nachala XX veka [Voting Procedures in Small Groups from Earliest Times until the Early $20^{\text {th }}$ Century]. Moscow, 2014. 76 p. (In Russ.).

4. Vol'skiy V. I., Karpov A. V. Primenenie raz lichnykh variantov pravila peredachi golosov [Application of Different Versions of Single 
начала XX века. М.: Высш. шк. экономики, $2014.76 \mathrm{c}$

4. Вольский В. И., Карпов А. В. Применение различных вариантов правила передачи голосов // Полития. 2011. № 2. С. 162-174.

5. Демина Н. Метод маркиза Кондорсе, или светлый путь спасения демократии. URL: http://www.polit.ru/article/2010/05/21/maskin condorset (дата обращения: 01.01.2017).

6. Зарубежное избирательное право: учеб. пособие / под ред В. В. Маклакова. М.: Норма, 2003. $288 \mathrm{c}$.

7. Иванченко А. А., Кынев А. В., Любарев А. Е. Пропорциональная избирательная система в России: История, современное состояние, перспективы. М.: Аспект Пресс, 2005. 333 с.

8. Конституционное (государственное) право зарубежных стран Часть обшая / под ред. Б. А. Страшуна. М.: Изд-во БЕК, 2000. Т. $1,2$. Б. A. C.
$784 \mathrm{c}$.

9. Сравнительное конституционное право: учеб. пособие / под ред. В. Е. Чиркина. М.: Междунар. отношения, 2002. 448 c.

10. Худолей $К . M$. Нужен ли конституционный (уставный) суд в субъекте РФ? // Вестник Пермского университета. Юридические науки. 2016. Вып. 4(34). С. 391-401

11. Arrow K. J. Social Choice and Individual Values: Wiley. N. Y., $1951.124 \mathrm{p}$.

12. Bartoldi J., Tovey C., Trick M. Voting Schemes for Which it Can be Difficult to Tell Who Wo the Election // Social Choice and Welfare. 2006. Vol. 2. Pp. 157-165. DOI: 10.1007/BF00 303169 .

13. LeGrand R. Descriptions of ranked-ballot voting methods. URL: http://www.cs. wustl.edu/ ing methods. URL: http://www.cs.wustl.edu/
legrand/rbvote/desc.htlm (дата обращения: legrand/rbv

14. McLean I. E. J. Nanson, Social Choice and Electoral Reform // Australian Journal of Political Science. 1996. Vol. 31, Iss. 3. Pp. 369-385.

15. Reilly B. Social Choice in the South Seas: Electoral Innovation and the Borda Count in the Pacific Islands Countries // Political Science Review. 2002. Vol. 23, Issue 4. Pp. 355-372.

16. Reynolds A., Reilly B., Ellis A. Electoral System Design: The New International IDEA Handbook. Stockholm, 2008. 237 p.

17. Shulze M. A New Monotonic, Clone-independent, Reversal Symmetric, and Condorsetconsistent Single-winner Election Method // Social Choice and Welfare. 2011. Vol. 26. Pp. 267-303.

18. Smith $W$ Descriptions of voting systems. URL: http://www.m-shulze.9mail de/votedesc. pdf (дата обращения: 01.01.2017).
19. Tideman N. Collective Decisions and Voting The Potential for Public Choice. Burlington, 2006. $337 \mathrm{p}$

20. Young H. P. Optimal Voting Rules // Journal of Economic Perspectives. 1995. Vol. 1. Pp. 51-64.

\section{References}

1. Belov S. A. Sistemnoe pravovoe regulirovanie izbiratel'noy sistemy [System Legal Regulatio of Electoral System]. Rossiyskiy yuridicheskì zhurnal - Russian Juridical Journal. 2011. Issue 1. Pp. 88-100. (In Russ.)

2. Berlyavskiy L. G. Sravnitel'noe izbiratel'noe pravo [Comparative Suffrage]. Moscow, 2013. 240 p. (In Russ.).

3. Vol'skiy V. I. Protsedury golosovaniya $v$ malykh gruppakh $s$ drevneyshikh vremen do nachala XX veka [Voting Procedures in Small Groups from Earliest Tim unt the Early $20^{\text {th }}$ Ce fory

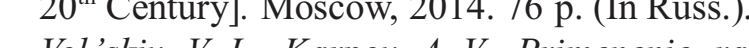
lichnykh variantov pravila peredachi golosov Application of Different Versions of Single Transferable Vote System]. Politiya - Politei 2011. Issue 2. Pp. 162-174. (In Russ.)

5. Demina N. Metod markiza Kondorse, ili svetlyy put' spaseniya demokratii [The Marquis de Condorcet Method, or the Bright Way of the Rescue of Democracy]. Available at: http://www.polit.ru/article/2010/05/21/maskin condorset. (In Russ.).

6. Zarubezhnoe izbiratel'noe pravo: ucheb. posobie / pod red. V. V. Maklakova [Foreign Suffrage: Textbook; ed by V. V. Maklakov]. Moscow, 2003. 288 p. (In Russ.).

7. Ivanchenko A. A., Kynev A. V., Lyubarev A. E. Proportsional'nava izbiratel'naya sistema Rossii: Istoriya, sovremennoe sostoyanie, perspektivy [Proportional Electoral System in Rusia: History, Current State, Prospects]. Moscow, 2005. 333 p. (In Russ.).

. Konstitutsionnoe (gosudarstvennoe) pravo zarubezhnykh stran: Chast' obschaya / pod red. B. A. Strashuna [Constitutional (State) Law of Foreign Countries: General Part; ed. by B. A. Strashun]. Moscow, 2000. Vols. 1-2. 784 p. (In Russ.)

9. Sravnitel'noe konstitutsionnoe pravo: ucheb. posobie / pod red. V. E. Chirkina [Comparative Constitutional Law: Textbook; ed by V. E Chirkin] Moscow, 2002.448 p. (In Russ.).

10. Khudoley $K$. M. Nuzhen li lonsturiony

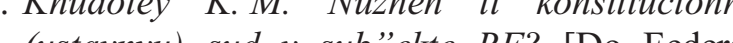
Sujur sud vis Subjects of Russia Need Constitutional (StatuYuridicheskie Nauki - Perm University Herald.
Transferable Vote System]. Politiya - Politeia. 2011. Issue 2. Pp. 162-174. (In Russ.)

5. Demina N Metod markiza Kondorse ili svetty put' spaseniya demokratii [The Marquis de Condorcet Method, or the Bright Way of the Rescue of Democracy]. Available at: http://www.polit.ru/article/2010/05/21/maskin condorset. (In Russ.)

6. Zarubezhnoe izbiratel'noe pravo: ucheb. posobie / pod red. V. V. Maklakova [Foreign Suffrage: Textbook; ed. by V. V. Maklakov]. Moscow, 2003. 288 p. (In Russ.)

7. Ivanchenko A. A., Kynev A. V., Lyubarev A. E. Proportsional'naya izbiratel'naya sistema $v$ Rossii: Istoriya, sovremennoe sostoyanie, perspektivy [Proportional Electoral System in Russia: History, Current State, Prospects]. Moscow, 2005. 333 p. (In Russ.)

8. Konstitutsionnoe (gosudarstvennoe) pravo zarubezhny stran: Chast' obscher pravo

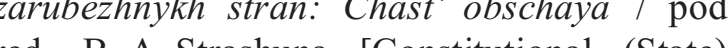
red. B. A. Strashina [Constitutional (State) Law of Foreign Conties: General Part; ed. by B. A. Strashun]. Moscow, 2000. Vols. 1-2. 784 p. (In Russ.).

9. Sravnitel'noe konstitutsionnoe pravo: ucheb. posobie / pod red. V. E. Chirkina [Comparative Constitutional Law: Textbook; ed. by V. E. Chirkin]. Moscow, 2002. 448 p. (In Russ.)

10. Khudoley K. M. Nuzhen li konstitucionny (ustavnyn) sud $v$ sub"ekte RF? [Do Federal Subjects of Russia Need Constitutional (Statutory) Courts?]. Vestnik Permskogo universiteta. Yuridicheskie Nauki - Perm University Herald. Juridical Sciences. 2016. Issue 4(34). Pp. 391401. (In Russ). DOI: 10.17072/1995-41902016-34-391-401.

11. Arrow K. J. Social Choice and Individual Values. New York, John Wiley \& Sons, 1951 124 p. (In Eng.).

12. Bartoldi J., Tovey C., Trick M. Voting Scheme for which it Can be Difficult to Tell Who Wo the Election. Social Choice and Welfare. 2006 Vol. 2. Pp. 157-165. (In Eng.). DOI: 10.1007/ BF00303169

13. LeGrand R. Descriptions of ranked-ballot voting methods. Available at: http://www.cs. wustl.edu/ legrand/rbvote/desc.htlm. (In Eng.)

14. McLean I. E. J. Nanson, Social Choice and Electoral Reform. Australian Journal of Political Science. 1996. Vol. 31. Issue 3. Pp. 369385. (In Eng.). DOI: 10.1080/10361149651102.

15. Reilly B. Social Choice in the South Seas: Electoral Innovation and the Borda Count in the Pacific Islands Countries. Political Science Revien 2002. Vol. 23. Issue 4. Pp. 355-372. (In Eng.). DOI: 10.1177/0192512102023004002
16. Reynolds A., Reilly B., Ellis A. Electoral System Design: The New International IDEA Handbook. Stockholm, 2008. 237 p. (In Eng.).

17. Shulze M. A New Monotonic, Clone-Independent, Reversal Symmetric, and CondorcetConsistent Single-Winner Election Method. Social Choice and Welfare. 2011. Vol. 26 Pp. 267-303. (In Eng.)

18. Smith $W$. Descriptions of voting systems. Available at: http://www.m-shulze.9mail.de votedesc.pdf. (In Eng.)

19. Tideman N. Collective Decisions and Voting The Potential for Public Choice. Burlington, 2006. 337 p. (In Eng.)

20. Young H. P. Optimal Voting Rules. Journal of Economic Perspectives. 1995. Vol. 1. Pp. 51-64. (In Eng.)

\section{References in Russian}

1. Белов С. А. Системное правовое регулирорание избирательной системы // Российский оридический журнал. 2011. № 1. С. 88-100.

2. Берлявский Л. Г. Сравнительное избирательное право. М.: Юрлитинформ, 2013. 240 с.

3. Вольский В. И. Процедуры голосования малых группах с древнейших времен до начала XX века. М.: Высш. шк. экономики, $2014.76 \mathrm{c}$

4. Вольский В. И., Карпов А. В. Применение разлов // Полития. 2011. № 2. С. 162-174.

5. Демина $H$. Метод маркиза Кондорсе, или светлый путь спасения демократии. URL: http://www.polit.ru/article/2010/05/21/maskin condorset (дата обращения: 01.01.2017).

6. Зарубежное избирательное право: учеб. пособие / под ред В. В. Маклакова. М.: Норма, $2003.288 \mathrm{c}$

7. Иванченко А. А., Кынев А. В., Любарев А. Е. Пропорциональная избирательная систем в России: История, современное состояние, перспективы. М.: Аспект Пресс, 2005. $333 \mathrm{c}$

8. Конституционное (государственное) право зарубежных стран. Часть общая / под ред. Б. А. Страшуна. М.: Изд-во БЕК, 2000. Т. 1, 2 . $784 \mathrm{c}$

9. Сравнительное конституционное право учеб. пособие / под ред. В. Е. Чиркина. М.: Междунар. отношения, 2002. $448 \mathrm{c}$.

10. Худолей $K . M$. Нужен ли конституционный (уставный) суд в субъекте РФ? // Вестник Пермского университета. Юридические науки. 2016. Вып. 4(34). С. 391-401.

11. Arrow K. J. Social Choice and Individual Va ues: Wiley. N. Y., 1951. $124 \mathrm{p}$ 
Juridical Sciences. 2016. Issue 4(34). Pp. 391401. (In Russ.). DOI: 10.17072/1995-41902016-34-391-401.

11. Arrow K. J. Social Choice and Individual Values. New York, John Wiley \& Sons, 1951. 124 p. (In Eng.).

2. Bartoldi J., Tovey C., Trick M. Voting Schemes for which it Can be Difficult to Tell Who Won the Election. Social Choice and Welfare. 2006. Vol. 2. Pp. 157-165. (In Eng.). DOI: 10.1007/ BF00303169.

13. LeGrand R. Descriptions of ranked-ballot voting methods. Available at: http://www.cs. wustl.edu/ legrand/rbvote/desc.htlm. (In Eng.)

14. McLean I. E. J. Nanson, Social Choice and Electoral Reform. Australian Journal of Political Science. 1996. Vol. 31. Issue 3. Pp. 369-

15. Reilly $B$. Social Choice in the South Seas: ElecRerly B. Social Choice en the South Ses: Elec-

cific Islands Countries. Political Science Review. 2002. Vol. 23. Issue 4. Pp. 355-372. (In Eng.). DOI: $10.1177 / 0192512102023004002$.

16. Reynolds A., Reilly B., Ellis A. Electoral System Design: The New International IDEA Handbook. Stockholm, 2008. 237 p. (In Eng.).

17. Shulze M. A New Monotonic, Clone-Independent, Reversal Symmetric, and CondorcetConsistent Single-Winner Election Method. So cial Choice and Welfare. 2011. Vol. 26 Pp. 267-303. (In Eng.).

18. Smith $W$. Descriptions of voting systems. Available at: http://www.m-shulze.9mail.de votedesc.pdf. (In Eng.)

19. Tideman N. Collective Decisions and Voting: The Potential for Public Choice. Burlington, 2006. 337 p. (In Eng.).

20. Young H. P. Optimal Voting Rules. Journal of Economic Perspectives. 1995. Vol. 1. Pp. 51-64. (In Eng.).
12. Bartoldi J., Tovey C., Trick M. Voting Schemes for Which it Can be Difficult to Tell Who Wo the Election $/ /$ Social Choice and Welfare. 2006. Vol. 2. Pp. 157-165. DOI: 10.1007/BF00
303169.

13. LeGrand R. Descriptions of ranked-ballot voting methods. URL: http://www.cs.wustl.edu/ - legrand/rbvote/desc.htlm (дата обращения: 01.01.2017).

14. McLean I. E. J. Nanson, Social Choice and Electoral Reform // Australian Journal of Political Science. 1996. Vol. 31, Iss. 3. Pp. 369-385.

15. Reilly B. Social Choice in the South Seas: Electoral Innovation and the Borda Count in the Pacific Islands Countries // Political Science Review. 2002. Vol. 23, Issue 4. Pp. 355-372.
16. Reynolds A., Reilly B., Ellis A. Electoral System Design: The New International IDEA Handbook. Stockholm, 2008. $237 \mathrm{p}$

17. Shulze M. A New Monotonic, Clone-independent, Reversal Symmetric, and Condorsetconsistent Single-winner Election Method // Social Choice and Welfare. 2011. Vol. 26. Pp. 267-303.

18. Smith $W$. Descriptions of voting systems. URL: http://www.m-shulze.9mail.de/votedesc pdf (дата обращения: 01.01.2017).

19. Tideman N. Collective Decisions and Voting: The Potential for Public Choice. Burlington, 2006. $337 \mathrm{p}$.

20. Young H. P. Optimal Voting Rules // Journal of Economic Perspectives. 1995. Vol. 1. Pp. 51-64. 